Portland State University

PDXScholar

10-11-1993

\title{
Cross-Cultural Comparison of Upward Compliance- Gaining Strategies: U.S.A. and Japan
}

Miyoko Fuse

Portland State University

Follow this and additional works at: https://pdxscholar.library.pdx.edu/open_access_etds

Part of the Speech and Rhetorical Studies Commons

Let us know how access to this document benefits you.

\section{Recommended Citation}

Fuse, Miyoko, "Cross-Cultural Comparison of Upward Compliance-Gaining Strategies: U.S.A. and Japan" (1993). Dissertations and Theses. Paper 4665.

https://doi.org/10.15760/etd.6549

This Thesis is brought to you for free and open access. It has been accepted for inclusion in Dissertations and Theses by an authorized administrator of PDXScholar. Please contact us if we can make this document more accessible: pdxscholar@pdx.edu. 
AN ABSTRACT OF THE THESIS OF Miyoko Fuse for the Master of Arts in Speech Communication presented October 11, 1993.

Title: Cross-Cultural Comparison of Upward ComplianceGaining Strategies: U.S.A. and Japan

APPROVED BY THE MEMBERS OF THE THESIS COMMITTEE:

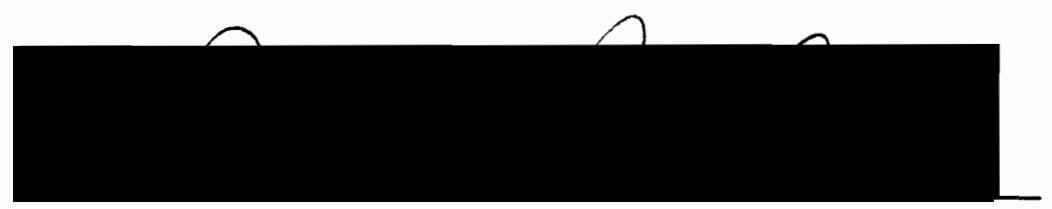

L. David Ritchie, Chair

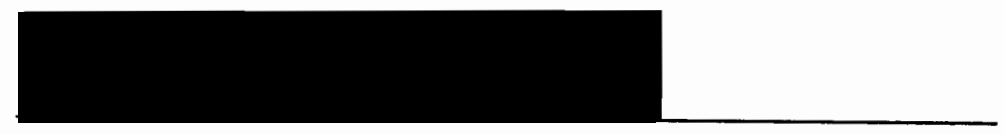

Susan B. Poulsen

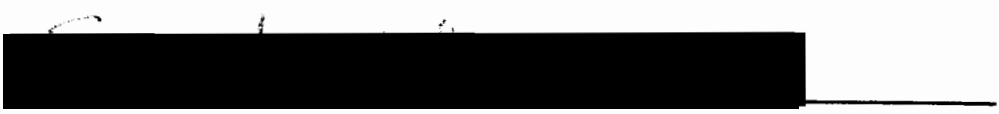

Suwako Watanabe

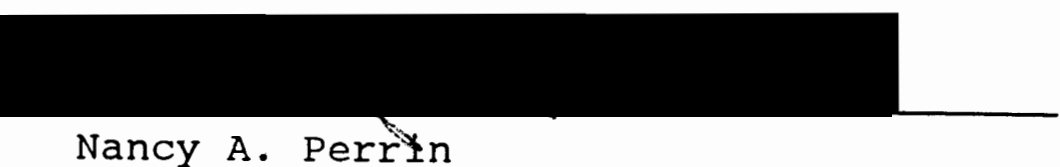

This study investigated cultural differences, U.S.A. and Japan, in the selection of compliance-gaining strategies by lower status people as differentiated from a group leader in a short-term, task-oriented relationship. The subjects for this study consisted of 114 (59 male and 55 female) U.S. 
college students and 165 (65 male and 100 female) Japanese college students. All subjects lived in oregon.

After the subjects read the hypothetical scenario which involved changing a task for a classroom project, a 21 item questionnaire was administered. The questions were taken from Kipnis, Schmidt, and Wilkinson's (1980) study, and a six-point scale was used. The 21 questions were categorized into four compliance-gaining strategies: rationalization, exchange of benefits, ingratiation, and assertion. Rationalization and exchange of benefits were used to test hypotheses regarding culture as a whole. Hypothesis one was "Japanese lower status people who are in short-term, taskoriented relationships will use more rationalization compliance-gaining strategies than U.S. people who are in short-term, task-oriented relationships," while hypothesis two was "U.S. lower status people who are in short-term, task-oriented relationships will use more exchange of benefits compliance-gaining strategies than Japanese lower status people who are in short-term, task-oriented relationships." Ingratiation and assertion were used to test the hypotheses regarding gender in different cultures. Hypothesis three was "U.S. lower status females who are in short-term, task-oriented relationships will use more ingratiation compliance-gaining strategies than Japanese lower status females who are in short-term, task-oriented relationships," and hypothesis four was "U.S. lower status 
males who are in short-term, task-oriented relationships use more assertion compliance-gaining strategies than Japanese lower status males who are in short-term, task-oriented relationships."

Multivariate Analysis of Variance (MANOVA) revealed there were significant differences in culture $(\underline{p}<.001)$ and sex $(p<.05)$. No significant differences were found in the culture by sex interaction. Hypotheses regarding exchange of benefits and ingratiation were supported by the results while hypotheses regarding rationalization and assertion were not supported by the results. The results of this study showed that, overall, relatively greater use of ingratiation, exchange of benefits, and rationalization compliance-gaining strategies appear to be associated with members of U.S. culture, while greater use of assertion compliance-gaining strategies appear to be associated with members of Japanese culture. 


\title{
CROSS-CULTURAL COMPARISON OF \\ UPWARD COMPLIANCE-GAINING STRATEGIES: \\ U.S.A. AND JAPAN
}

by

MIYOKO FUSE
A thesis submitted in partial fulfillment of the requirements for the degree of

\author{
MASTER OF ARTS \\ in \\ SPEECH COMMUNICATION
}

Portland State University

1993 
TO THE OFFICE OF GRADUATE STUDIES:

The members of the Committee approve the thesis of Miyoko Fuse presented October 11, 1993.

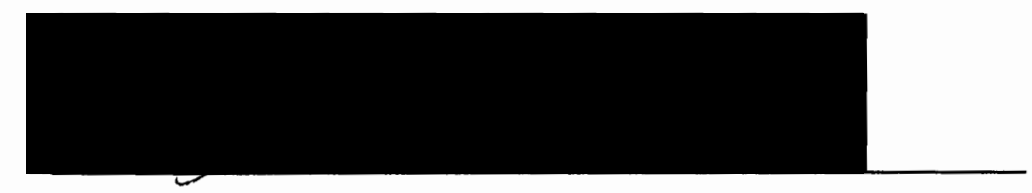

L. David Ritchie, Chair

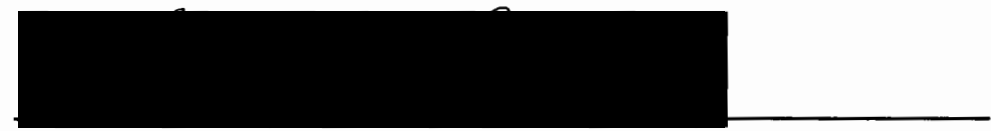

Susan B. Poulsen

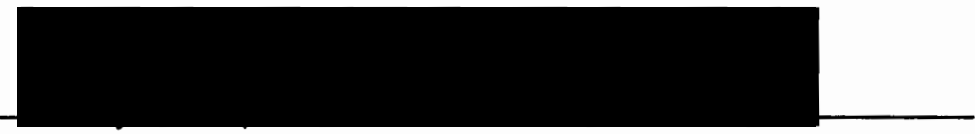

Suwako Watanabe

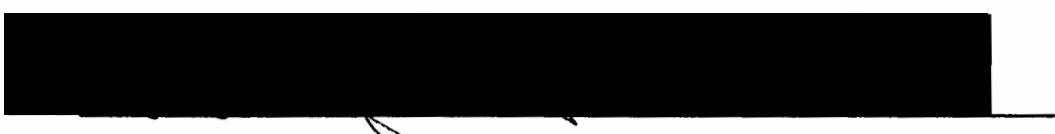

Nancy A. Perrin

APPROVED :

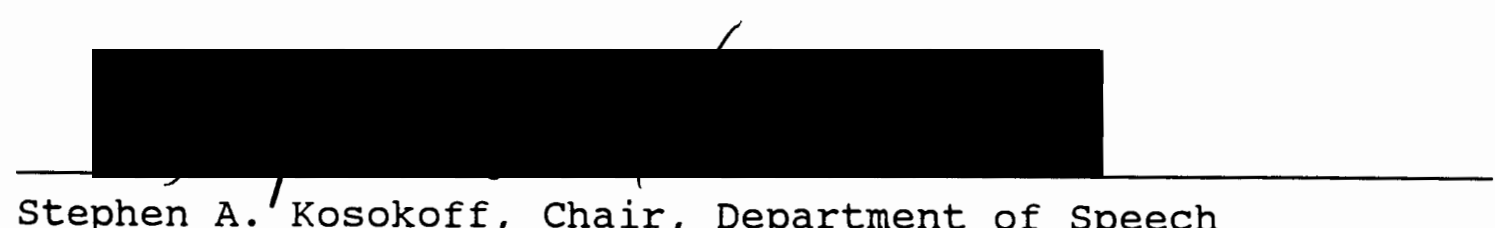

Stephen A. Kosokoff, Chair, Department of Speech Communication

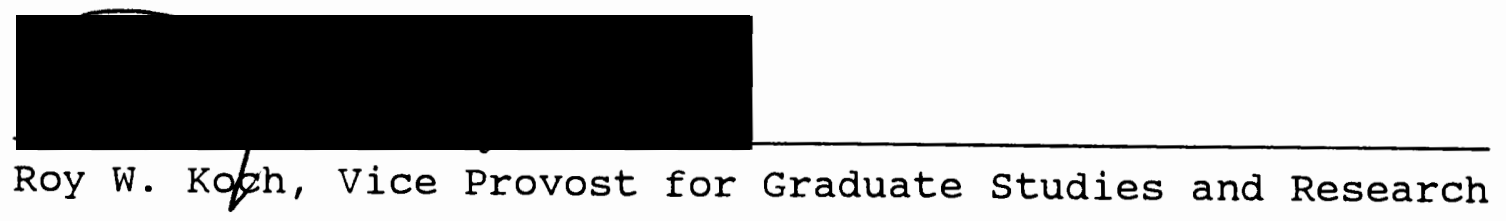


To my husband, Charles A. Roddy 


\section{ACKNOWLEDGEMENTS}

First of all, I would like to thank Dr. Ritchie, chair thesis advisor, who navigated and supervised my thesis. His generous support through e-mail communication made the complicated process easier and encouraged me to accomplish my goal. I was fortunate to have Dr. Poulsen's advice, and I appreciate her review of the theories involved. I gratefully thank Dr. Watanabe for her in-depth perception of Japanese culture. With her thorough review, my thesis became richer. I appreciate Dr. Perrin for her generosity and her enthusiasm for statistical analysis. Special thanks for my writing tutors for their patience and hard work. From time to time the tutors changed, but we all shared the enjoyment and agony of technical writing. I am thankful for all of my subjects and their instructors. With their participation in the survey, I was able to accomplish my research and thesis. I am also thankful to my friends. Sharing the experience was pleasurable.

This thesis has great meaning for my intercultural marriage. I have no words to show my appreciation to my husband, Charles A. Roddy. With his endless understanding, support, patience, and love, I was able to accomplish my thesis. He deserves to receive all of the compliments I have received for the work involved with my thesis. 
TABLE OF CONTENTS

PAGE

ACKNOWLEDGEMENTS..........................

LIST OF TABLES..........................

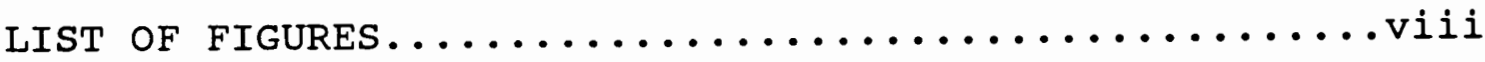

CHAPTER

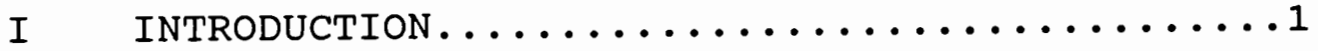

Justification..................

Purpose of the Study................

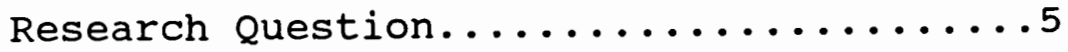

II THEORY CHAPTER.................

Compliance-gaining...............

Overview and Definition of Compliance-gaining Behavior Maintaining Interpersonal communication

Interpersonal Power

Upward Compliance-gaining Strategies

culture......................17

Collectivistic vs. Individualistic Vertical vs. Horizontal

Gender Differences in Compliance-gaining

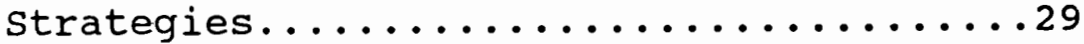

Stereotypes

Ingratiation Strategies and Women Assertion Strategies and Men

III METHOD........................ 
Research Design................43

Theoretical Model

Sample......................46

Sampling Frame

subjects

Instruments................48

Scenario

Variables

Procedures......................54

Translation

Pilot Study

Data Collection

Statistical Methods.................58

IV $\quad$ RESULTS........................

Sample Characteristics...........60

Responses and Subjects for This

study

Subjects' Characteristics

Reliability................61

Evaluation of the Scenario and Group Projects

Reliability

overall Statistical Analysis.........63

Descriptive Statistics

Multivariate Analysis of

variance (MANOVA)

Testing Hypotheses..............65

Hypothesis one

Hypothesis Two

Hypothes is Three

Hypothes is Four

Additional Analysis..............68 
Limitations...................69

Overall Limitations

For the U.S. Subjects

For the Japanese Subjects

Findings and Interpretation.........73

Overall Findings

Rationalization

Exchange of Benefits

Ingratiation

Assertion

Suggestions for Future Studies........93

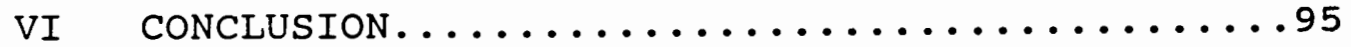

Theoretical Implications...........95

Methodological Implications..........97

Practical Contributions..............98

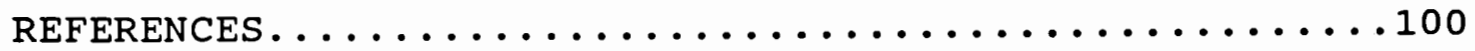

APPENDICES

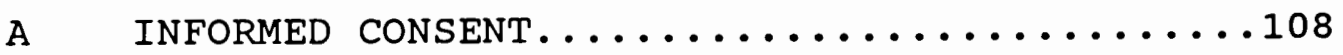

B COVER LETTER FOR THE SUBJECTS...........110

C DEMOGRAPHIC INFORMATION SHEET FOR THE U.S. SUBJECTS........................112

D DEMOGRAPHIC INFORMATION SHEET FOR THE JAPANESE SUBJECTS........................114

E SCENARIO FOR THE U.S. SUBJECTS.........116

F SCENARIo For THE JAPANESE SUBJECTS.......118

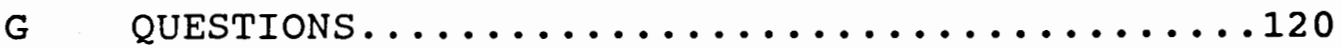

H COVER LETTER FOR JAPANESE LANGUAGE

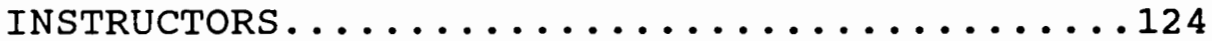

I COVER LETTER FOR INSTRUCTORS OF JAPANESE

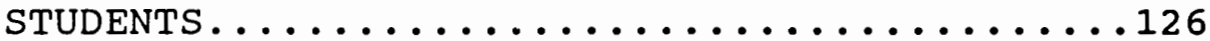

J JAPANESE TRANSLATIONS.............. 128 
LIST OF TABLES

TABLE

PAGE

I Reliability coefficients for Four Compliancegaining Strategies Used by U.S. and Japanese Subjects..........................63

II Means and Standard Deviations for Rationalization, Exchange of Benefits, Ingratiation, and Assertion.............64

III Means and Standard Deviations for

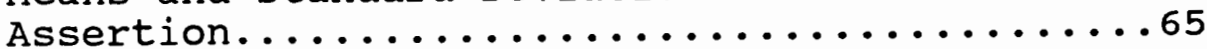

IV Means and Standard Deviations for Ingratiation Strategies Used by U.S. and Japanese Females..67

V Means and Standard Deviations for Assertion Strategies Used by U.S. and Japanese Males...67 


\section{LIST OF FIGURES}

FIGURE

PAGE

1 Relationship Among the Three Variables, with

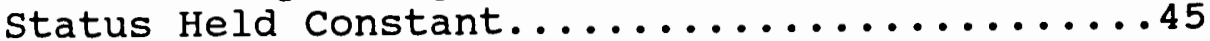


CHAPTER I

INTRODUCTION

JUSTIFICATION

The increasing population of temporary intercultural residents, such as students or business people, is a worldwide phenomenon. Increased intercultural contact between the U.S. and Japan is demonstrated by, among other things, the increase of Japanese language classes for the U.S. populace in general (Jorden, 1991) and the large population of Japanese students in the U.S. (Zikopoulos, sutton, \& Julian, 1992), as well as the high number of international business ventures. Because of their geographical location on the Pacific Rim and their relationship as trading partners, Oregon and Japan maintain a high degree of contact with each other, especially in education and business. Japanese colleges have established their branches in oregon (Ota, 1989; Read, 1991), and the Japanese economic

investment in oregon is growing rapidly (Bain, 1991).

A reflection of the success of Japanese business is the considerable number of Japanese style management handbooks available in the U.S. Yet, our everyday intercultural 
contact is not limited just to managerial levels. In fact in most organizations, including educational institutions, the number of lower status people, such as workers or students, is much greater than that of higher status people, such as managers or teachers. This study will focus on the communication behavior of lower status people toward higher status people--an area that previous research has somewhat neglected (Porter, Allen, \& Angle, 1981; Schilit \& Locke, 1982; Tierney, 1989).

Certain characteristics of lower status people's communication behavior have been established by previous research. Generally, lower status people are considered to lack the power and influence of higher status people, which makes them less likely to employ "risky" communication strategies, such as "threatening or intentionally annoying" (Tierney, 1989, p. 7) and makes them more likely to be sensitive to the need for maintaining a good relationship with people of higher status (Cohen, 1958; Waldron, 1991). At the same time, while maintaining this relationship, lower status people do try to gain what they want from their leaders; they do select strategies to influence and gain compliance from them. Thus, lower status people are more likely to select specific compliance-gaining strategies that might help maintain their relationship with higher status people (Waldron, 1991).

The selection of a specific compliance-gaining strategy 
varies according to the nature of the relationship (Marwell \& Schmitt, 1967), and the selection is culture-specific (Neuliep \& Hazelton, 1985; Schermerhorn \& Bond, 1991). This may be especially true for lower status people. Higher status people have the advantage of additional training, which provides them with a greater repertoire of communication strategies (Kipnis \& Schmidt, 1984). In other words, lower status people, without experience or training in managerial skills, may well retain their own cultural communication styles to a greater degree than higher status people who have been trained for managerial positions and who use communication learned through their training.

Because cultural values differ, the communication of a lower status person who uses his or her culturallyinfluenced compliance-gaining strategies might be misinterpreted by a higher status person who is from a different culture. In order to have good intercultural relationships and to avoid misinterpretation, it is important to understand the communication styles that lower status people use in different cultures.

\section{PURPOSE OF THE STUDY}

Compliance-gaining behavior has been studied in managerial fields as it pertains to the power of leadership (e.g., Harper \& Hirokawa, 1988; Hirokawa \& Miyahara, 1986; 
Sullivan, Albercht, \& Taylor, 1990). Most studies about compliance-gaining strategies have focused on downward communication (from a superior to a subordinate) because their purpose is to find effective management styles and therefore increase production. Only a few studies about upward influence strategies (from a subordinate to a superior) have been done (e.g., Kipnis, Schmidt, \& Wilkinson, 1980; Porter, Allen, \& Angle, 1981; Schermerhorn \& Bond, 1991; Tierney, 1989). In spite of the fact that, proportionally, there are many more lower status people than higher, researching upward communication strategies in relationship with intercultural communication is even rarer (Schermerhorn \& Bond, 1991). The present study of comparison of cross-cultural upward compliance-gaining strategies attempts to contribute to an understanding of lower status people's communication styles in different cultures.

Because culturally differing communication behaviors often cause conflict and confusion, and contribute to racial prejudice, knowing how a person from another culture communicates with and tries to gain compliance from higher status people will provide an opportunity for fairer treatment. This fair treatment contributes to the psychological well-being and enhanced performance of not only lower status people but higher status people as well. In addition, due to a current increase in short-lived, 
task-oriented intercultural relationships, such as those encountered in business and research projects, now more than ever it is critical to understand the communication styles used by lower status people, both in the U.S. and Japan. Accordingly, this study will examine lower status people's selection of upward compliance-gaining strategies in both U.S. and Japanese culture.

\section{RESEARCH QUESTION}

Compliance-gaining strategies differ in the U.S. and Japan because culture greatly influences communication styles. It is assumed that in short-term relationships an individual without extensive intercultural experience communicates according to his or her own culturally determined communication style (Bennett, 1986). The research question proposed is the following:

How do Japanese people and U.S. people who are in short-term, task-oriented relationships compare in their use of various tactics of upward influence? 
CHAPTER II

\section{THEORY CHAPTER}

People desire to gain compliance from other people regardless of culture, gender, or status. However, the way a person tries to gain compliance differs according to his or her cultural background (Neuliep \& Hazleton, 1985; Schermerhorn \& Bond, 1991), gender (Johnson, 1976), and status in an interpersonal relationship (Kipnis, schmidt, \& Wilkinson, 1980). Because communication behavior is relatively predictable in a given relationship (Shimanoff, 1980), the listener is more likely to respond favorably to the requester if the person making a request uses behavior which is predicted and/or expected by the other person. Thus, mutually understood communication behavior or a familiarity with the communication behavior of another person is more likely to lead to successful compliancegaining (Burgoon, Dillard, \& Doran, 1983; Falbo, 1977b). In contrast, a requester's behavior which the listener cannot predict or which he or she perceives as different from his or her expectations may make the listener become defensive (Bennett, 1986); thus, the requester's chances of gaining compliance are less. 
People consciously or unconsciously attempt to select influential communication behaviors appropriate to or expected in a given relationship. This appropriate and/or expected behavior is crucial in order for a requester to gain compliance. Thus, the premise of this study is that people will use appropriate or expected compliance-gaining strategies based on their status, gender, and particular culture.

\section{COMPLIANCE-GAINING}

overview and Definition of Compliance-gaining Behavior

Compliance-gaining behavior is one form of persuasion. Yet, while persuasion is traditionally studied in order to find effective message strategies used in one-to-many situations, such as a public speaker speaking to an audience (Miller \& Burgoon, 1978), compliance-gaining behavior is studied for one-to-one situations and includes many different influential strategies (Marwell \& Schmitt, 1967).

Marwell and Schmitt (1967) developed the first comprehensive taxonomy for compliance-gaining strategies used in many interpersonal situations. Unlike one-to-many persuasion, in which a persuader has higher status or, regardless of status, is perceived to be more expert in a specific area than others, one-to-one compliance-gaining behavior can be exercised by anybody. Therefore, lower 
status people also exercise compliance-gaining strategies toward higher status people (Kipnis, Schmidt, \& Wilkinson, 1980).

In fact, regardless of status differences, compliancegaining situations are common in our everyday lives (Kipnis, Schmidt, \& Wilkinson, 1980; Marwell \& Schmitt, 1967). Marwell and Schmitt (1967) stated that

it is clear that people spend a good deal of time trying to get others to act in ways they desire. It is equally clear that people vary in the ways they go about attempting such interpersonal control. (p. 350)

Marwell and Schmitt (1967) decided to focus their study on short-term compliance-gaining strategies because strategies used over a long period of time involve many different variables. A more recent study by Wheeless, Barraclough, and Stewart (1983) also stated that in compliance-gaining behavior a requester tries relatively sooner rather than later to change behavior or elicit new behavior in a requestee. These short-term compliance-gaining strategies occur in our day-to-day interpersonal communication.

For this study, the definition of compliance-gaining behavior will include the following conditions. It must be one-to-one interpersonal communication and consist of compliance-gaining strategies used by lower status people. The content of the request must be appropriate and relevant to the relationship, the task, and the focus of interaction. Compliance-gaining strategies are assumed to be used in 
communication where a request is made and a response is expected immediately.

Maintaining Interpersonal communication

Sociocultural experiences contribute to the development and expansion of each person's communication style (clark \& Delia, 1979). Clark and Delia (1979) stated that through interaction with others individuals learn and actively select appropriate communicative strategies for adapting to specific interpersonal relationships. Therefore, one's recognition of his or her communication objectives allows him or her to select specific strategies. Delia and o'Keefe (1979) stated that

The individual must create strategies which actualize his intentions, but which do so within the constraints imposed by contextually constituted definitions given to situation, self, other, relationship, and the focus of interaction. He must introduce his projects into the interactional agenda, securing for his concerns focused attention. The strategies generated thus must not only actualize his intention, but also must be appropriate within the constantly emerging definition given to reality in interaction. (pp. 180-181)

Selecting communication strategies which are adaptable to a particular interpersonal relationship enhances an individual's ability to accomplish communication objectives. Clark and Delia (1979) classified three communication objectives: maintenance of a desired self-image, accomplishment of a task, and maintenance of an interpersonal relationship. Clark and Delia (1979) stated 
that the three dimensions are integrated to some degree, although one of the objectives can be stronger than the others. In a relationship a person chooses communication strategies based at least in part on that individual's selfimage. Having a socially acceptable self-image helps a requester gain compliance (Falbo, 1977b). In addition, compliance-gaining behavior is goal-oriented and therefore closely related to the accomplishment of a personally defined goal (Clark, 1979; Clark \& Delia, 1979). A goaloriented communication behavior intended to gain compliance, such as making a request, can be interpreted as a threatening act by another person (Brown \& Levinson, 1987). Therefore, in order for a requester to both gain compliance and reduce a perceived threat, he or she chooses strategies which will be successful and appropriate for maintaining the specific relationship (Clark, 1979; Tierney, 1989). This is especially important for a requester whose status is lower than the other person.

In spite of the fact that the compliance-gaining behavior of a lower status person can be interpreted as a threatening act by a higher status person (Brown \& Levinson, 1987), task-oriented relationships usually remain stable (Waldron, 1991). The fact that members in a group share an expectation about what kinds of requests one can make in a given situation may contribute to this equilibrium. Even more important, however, lower status people have less 
control and, subsequently, less power in a relationship. Therefore, they feel more concern about making sure their communication enhances smooth relationships (Cohen, 1958; Waldron, 1991). Read (1962) stated that "'lows' behave toward 'highs' in a manner designed to maximize good relations and minimize feelings of unease in their interactions with high-power persons" (p. 3). Therefore, when lower status people try to gain compliance, they are more sensitive to maintaining relationships than higher status people are.

\section{Interpersonal Power}

Within a vertical power structure, a lower status person is functionally dependent upon a higher status person for satisfying his or her needs (e.g., Bradley, 1978; Cohen, 1958). Obviously, lower status people do not decide whether or not a request is pursued--higher status people do. Yet, because interpersonal communication is reciprocal in nature, a lower status person does have some power, at least to influence the other person if not to control him or her (Kipnis, Schmidt, \& Wilkinson, 1980; Yukl, 1981). What is this "influential power"? Describing the difference between "status" and "power," Bradley (1978) stated that

status was defined in terms of the value, importance, or prestige associated with a given role or position. Power, on the other hand, was related to the opportunity to influence or control the need association of others. (p. 35) 
So, while compliance-gaining behavior requires power, it does not necessarily require "status power" but, rather, influential or "interpersonal power" (e.g., Falbo, 1977a; Wheeless, Barraclough, \& Stewart, 1983). Wheeless et al. (1983) described interpersonal power this way: "[It] may be regarded as the perceived basis of control that a person has over another person's behavior that would not have otherwise occurred" (p. 120). Johnson (1976) offered a similar definition:

Interpersonal power may be defined as the ability to get another person to do or believe something he or she would not have necessarily done or believed spontaneously. (p. 100)

Interpersonal power, therefore, is actually one-to-one influential power used for gaining compliance regardless of status differences: Lower status people do have access to interpersonal power.

Classifications of influential power in interpersonal relationships have been offered by several researchers. The most well known classification is the study done by French and Raven (1959). They have developed a theory of the basis of social power which includes five kinds of power: reward, coercive, legitimate, expert, and referent. According to them, an interpersonal relationship is the source of this power which is then used to control another person in interpersonal relationships. However, other researchers (e.g., Falbo, 1977a; Kipnis, Schmidt, \& Wilkinson, 1980) have noted that while French and Raven's (1959) basis of 
social power focused on the person who possesses certain powers, it failed to take into account those lower status people who are still able to apply influence without possessing any of those powers. For example, Johnson (1976) not only classified applications of low-power as helplessness, hinting, and nagging, she also discussed women whose power is low but are still able to influence other people. Along the same lines, Falbo (1977a) mentioned deceit, persistence, and thought-manipulation. Whether interpersonal power is on the "high" side, such as threat or coercion, or the "low" side, such as "nagging", these types of powers underlie compliance-gaining strategies. Influential power, as it is related to interpersonal communication, is implemented in compliance-gaining behavior. Accordingly, Marwell and Schmitt (1967) used French and Raven's (1959) "basis of social power" as the underlying structure of their analysis of compliance-gaining strategies. Many other researchers (e.g., Falbo, 1977a; Howard, Blumstein, \& Schwartz, 1986; Johnson, 1976; Kipnis, Schmidt, \& Wilkinson, 1980) who study power and strategies use the concept of interpersonal power and compliancegaining strategies interchangeably. Those studies include not only extreme means, such as threats or nagging, but also strategies considered to be neutral and which are neither direct nor indirect, such as the exchange of benefits (Howard et al., 1986; Kipnis et al., 1980), or 
rationalization (Kipnis et al., 1980). Interpersonal power is expressed using a wide range of these compliance-gaining strategies by a variety of people in many different situations.

Upward Compliance-gaining strategies

Although one can exercise many different kinds of interpersonal power to gain compliance, in a task-oriented relationship, selecting appropriate compliance-gaining strategies affects both the gaining of compliance and maintenance of relationships. Social approval and social expectation influence the communication strategies of lower status people: Lower status people select different compliance-gaining strategies than higher status people (Kipnis, Schmidt, \& Wilkinson, 1980; Schriesheim \& Hinkin, 1990). Meeting social expectations allows people to gain compliance more successfully than not meeting them (e.g., Burgoon, Dillard, Doran, 1983; Falbo, 1977b) . Such expectations for lower status people are often described as their using covert or indirect strategies. Singh (1988) demonstrated that lower-level managers tend to use subtle power strategies to influence immediate supervisors. Kipnis et al. (1980) found that people in a weak position used ingratiation as an indirect strategy. Ingratiation is seemingly an effective strategy used in task-oriented relationships. Kipnis and schmidt (1984) found that using 
ingratiation in the work place was favorably perceived by the workers. DuBrin (1991) also found an association between shorter experience at a particular work place and the use of ingratiation.

However, not only are indirect strategies used to meet social expectation, but directness is used as well. For example, males who have lower status may use a direct strategy such as assertion. Kipnis, schmidt, and wilkinson (1980) found that lower status people used assertion as well as indirect strategies. Gaa, Liberman, and Edwards (1979) stated that assertion was a masculine stereotype and they listed its characteristics, such as, "willing to take risks [or be] forceful" (p. 594). Males may use assertion strategies to meet social sex-role expectations. It may seem unexpected that lower status people would use assertion to gain compliance; however, the clear, non-manipulative, and timesaving characteristics of directness (Brown \& Levinson, 1987) contribute to lower status people's ability to gain compliance in a short period of time.

In addition to direct and indirect strategies, a person may also use neutral (neither direct nor indirect) strategies such as logical reasoning. Logical reasoning or rationalization as a compliance-gaining behavior can be used by a person who has either higher or lower status (Kipnis, Schmidt, \& Wilkinson, 1980). Falbo's (1977a) study about power strategy showed that reasoning is associated with a 
person's social skill; subjects who used reasoning received a positive evaluation. Reasoning, which is how well a person can explain an issue, and social skills are both related to the level of comfort that a requester has in a relationship with another person or group. Therefore, it can be said that a person who uses reasoning usually has good social skills. Falbo's (1977a) study showed that people who used reasoning were more likely to conform to group pressure. Tierney's (1989) study reinforced the relationship between a person's level of comfort and the use of logical reasoning to gain compliance. That is, an increased level of comfort in a given relationship is positively associated with an increased use of logical reasoning.

In a similar vein, exchange of benefits as a neutral strategy, which is neither direct nor indirect, is used to gain compliance. A lower status person's perceived relationship closeness to a higher status person in an interpersonal relationship may contribute to the lower status person's choosing exchange of benefits. In other words, in a given interpersonal relationship, a lower status person might feel comfortable enough to offer exchange as a means of "give and take." An exchange of benefits strategy such as promising (Neuliep \& Hazleton, 1985) or offering, such as when the requester will "make personal sacrifices" (Kipnis, Schmidt, \& Wilkinson, 1980), is used by people who 
are unable to use stronger strategies but who are also unwilling to use weak strategies (Howard, Blumstein, \& Schwartz, 1986). At the same time, exchange of benefit gives the listener a clear idea of what is going on in the relationship.

One should keep in mind, therefore, that lower status people try to maintain a good relationship with higher status people in order to gain compliance. They do select strategies within a certain framework; however, regardless of the strategies they choose for influencing higher status people, the ultimate goal is to benefit themselves.

\section{CULTURE}

Communication styles and culture are an intrinsic part of individuals. Individuals' cultural perceptions and communication styles are passed from generation to generation and are persistent and enduring (Porter \& Samovar, 1988). Using a computer metaphor, Porter and Samovar suggested that "as we program computers to do what they do, our culture to a great extent programs us to do what we do and to be what we are" (p. 20). Thus, in order to understand another culture's communication strategies, it is necessary to know that culture.

Because compliance-gaining strategies are culturespecific (Neuliep \& Hazleton, 1985; Schermerhorn \& Bond, 
1991), one culture's compliance-gaining strategies are not necessarily appropriate in another culture. For example, U.S. people may try to influence Japanese people by being friendly, but this may embarrass the Japanese. Japanese people may try to influence U.S. people by being numble, and this may cause frustration for U.S. people.

This section will examine intercultural theories specifically related to cultural factors which affect compliance-gaining behavior. Two major cultural differences will be focused on: the orientation of self (collectivistic or individualistic) and the cultural value placed on hierarchical structure (vertical or horizontal).

\section{Collectivistic vs. Individualistic}

The way people present themselves to others is an important factor for a successful compliance-gaining strategy in a specific culture. One culture may value individuals who assert themselves, while another culture may value individuals who identify themselves with the group or groups to which they belong.

These cultural values, which are related to group membership and sense of self, are described as collectivistic or individualistic. Hofstede (1984) has described a collectivistic culture as emphasizing the importance of the group and an individualistic culture as emphasizing the importance of the self. According to 
Hofstede (1984), Japan is a collectivistic culture and the U.S.A. is an individualistic culture. The difference between individualistic and collectivistic self-identity makes for different degrees of self-assertiveness.

In a collectivistic culture, the self-identity is established and maintained with an emphasis on the groups to which a person belongs. When a Japanese person identifies him or herself, he or she tends to say "I work for $\mathrm{X}$ corporation," or "I am a student of $\mathrm{Y}$ university" rather than "I am an X" (e.g., Fox, 1977; Nakane, 1970). For Japanese people, the connection with a group takes precedence over what he or she does (Nakane, 1970).

In contrast, the emphasis in an individualistic culture is on an individual's performance, achievements, and competitiveness (Triandis \& Albert, 1987). In an individualistic culture such as the U.S.A., an individual's relationship to groups is relatively loose and independent. An individual is related to a group through interests or tasks, but compared to collectivistic cultures, there is less emphasis on connections to groups (Hofstede, 1984; Stewart, 1971). Accordingly, a U.S. individual identifies him or herself by referring to what he or she specifically does (Stewart, 1971).

In a collectivistic culture such as that of Japan, dependency is essential to group harmony (Cathcart \& Cathcart, 1988; Doi, 1962). In Japan, showing dependence is 
a form of identifying oneself with one's group. This dependency is referred to as "amae" and permeates Japanese society. Doi (1962) described "amae" as a Japanese national trait that "refers to what a small child feels toward his mother. It is therefore not surprising that the desire to 'amaeru' [a verb form of 'amae'] still influences one's adult years..." (p. 134). Brannen, Ramsey, Olsen, and wilt (1979) summarized the concept of amae as follows.

Amae may be understood as the desire to be dependent and the act of presuming upon another's love in that an individual's actions will be accepted. In such a relationship a certain amount of self-indulgence is permitted. Initially a feeling of total dependence is represented by a child's relationship with the mother during nursing and primary care giving. As one grows up, acceptance by a group, whether inside or outside the family, provides a circle of tenured relationships within which security and the opportunity for dependence can be found. (p. 478)

Japanese interactions are based on an implicit assumption of mutual dependence. Therefore, in order for Japanese people to maintain a harmonious relationship, they use a "safe" compliance-gaining strategy. In spite of making a request, which can be a potential threatening act (Brown \& Levinson, 1987), Japanese people try to gain compliance by explanation or rationalization, which do not imply strong persuasiveness in the U.S. perspective (Neuliep \& Hazleton, 1985). In Japanese culture, mutual dependency and understanding allow people to relatively freely explain their needs. This use of explanation by Japanese people was seen in a study done by Neuliep and Hazleton (1985). Their 
cross-cultural comparison of compliance-gaining in close relationships used by U.S. and Japanese student subjects showed that Japanese subjects used explanation as a strategy more often than did U.S. subjects.

DeMente (1981) stated that "the principle and practice of 'Amae' are certainly not unique to Japan, but the Japanese are apparently the only people... who made it the primary essence of their distinctive social system" (p. 16). These cultural differences are also reflected in differing value perceptions. Cathcart and Cathcart (1988) compared the perception of dependency in Japan and the U.S. They stated that

Dependency, in Japan, is considered a natural and desirable trait capable of producing warm human relationships. In America, on the other hand, dependency is considered a limitation on individual growth and fulfillment, and so the family and school teach the child to become selfreliant. (p. 188)

This quotation reflects the importance placed on selfreliance in U.S. culture where people are said to be responsible for taking care of themselves and their thoughts (eg., Hofstede, 1984; Stewart, 1971). Having a strong sense of individual identity leads a person to communicate independently of the influence of others. It is an individual's responsibility to gain compliance from another; these compliance-gaining strategies are related to one's own actions. Such actions show an individual's ability to negotiate for his or her own benefit. A U.S. individual 
actively bargains or exchanges what he or she can do for the other in order to gain compliance. A U.S. person may offer personal sacrifice (Kipnis, Schmidt, \& Wilkinson, 1980) or a promise (Neuliep \& Hazleton, 1985) as an exchange of benefit. Making this kind of effort is highly valued in an individualistic culture (Suzuki, 1991).

In addition to understanding differences between the ways in which individualistic and collectivistic culture use compliance-gaining strategies, it is also useful to understand cultural context. Hall (1976), in his anthropological research, described this concept and divided it into two types, high- and low-context. He stated that

A high-context (HC) communication or message is one in which most of the information is either in the physical context or internalized in the person, while very little is in the coded, explicated transmitted part of the message. A low-context (LC) communication is just the opposite; i.e., the mass of information is vested in the explicit code. (p. 91)

According to Hall (1976), Japan is primarily a high-context culture while the U.S. is primarily a low-context culture. Gudykunst and Nishida (1986) pointed out the relationship between cultural contexts and the predictability of another person's communication behavior. They stated that the predictability of other's communication behavior is related to direct communication styles in a low-context culture such as the U.S.A. and is related to indirect communication styles in a high-context culture such as Japan. Regarding high-context, Okabe (1983) stated that a 
high-context culture values interdependence and harmony. Emphasis on group harmony is seen in Ramsey's (1985) statement that

The Japanese know that direct expression of emotions or explicitly stating an opinion or preference may bring more negative than positive effects if one's relationship to the other is the primary concern. (p. 309)

In Hall's (1976) view, because of their relatively high-context culture, Japanese people tend to make less use of verbal communication and rely more on nonverbal communication than people in the U.S., who use more explicit verbal communication. Nomura and Barnlund's (1983) empirical research about verbal communication among U.S. people and Japanese people reinforced Hall's (1976) concept of cultural context. These researchers found that when Japanese people expressed criticism, they used more nonverbal communication than U.S. people. Barnlund and Araki's (1985) findings were similar. In their study on the use of compliments by Japanese people and by U.S. people, they also found that Japanese people used less verbal communication when compared with U.S. people. The knowledge of the cultural context which underlies people's culturally developed skill for expressing verbal communication or reading nonverbal communication might contribute to avoiding misjudgments of another culture's communication styles. 
Vertical vs. Horizontal

In order to gain compliance from another person, the requester tries to persuade the listener using strategies specific to that culture. The effectiveness of these strategies is influenced by the ways in which interpersonal relationships, such as hierarchical ones, are structured and perceived in a particular culture.

Japanese society has a hierarchical structure which leads to a formal communication style. Formality and informality are reflected in language use. The Japanese language has many honorifics and specific polite expressions. For example, when a Japanese person talks to a higher status person, the lower status person uses the higher status person's title such as professor $\mathrm{x}$ or manager Y (Suzuki, 1986). Although English has degrees of politeness, U.S. people differentiate less in the use of language according to status. For example, the pronoun "you" is used regardless of status differences in U.S. culture while Japanese people do not use "anata," which is the Japanese equivalent of "you," to higher status people (Jorden, 1987) .

Condon (1984) stated that the Japanese "acknowledge a social hierarchy--in the use of language, in seating arrangements at social gatherings, in bowing to one another and hundreds of others" (p. 20). There is always a vertical element to relationships, from fixed (e.g., mother and a 
child) to changeable, depending on the circumstance (e.g., friendship). A fixed vertical relationship structure is, for example, that of age or seniority. In Japan, younger people or juniors defer to older people or seniors. This vertical system is called senpai-kohai (senior-junior) bond. "Seniors" in a school are always deferred to by "juniors" regardless of their socioeconomic status or academic achievement. Once Japanese people have formed a senpaikohai bond, it continues even after graduating from school. Condon (1984) stated that

the sempai-kohai (senior-junior) bond which continues long after college and extends into the business world with favors sought and granted between the former students who are bound together because of--not in spite of--their differences in age. (p. 22)

In contrast, U.S. people exercise an informal communication style that can be characterized by the concept of egalitarianism. Egalitarianism has been recognized as an important U.S. cultural value for a long period of time (Buck, Newton, \& Muramatsu, 1984). Buck et al. (1984) stated that

In spite of the great differences in how people from various social, economic and ethnic groups were being treated, there was still a basic American value which held that all individuals should be free to achieve all that they were capable of achieving, economically as well as socially. (p. 281)

Although valuing egalitarianism does not necessarily reflect democratic practices, people's attitudes toward minimizing perceived differences are seen in the U.S. where people use 
relatively informal communication styles toward higher status people. Using a higher status person's first name is one example of this informal communication style (Okabe, 1983; Stewart, 1971). From the viewpoint of people in an egalitarian culture, status, or age differences, which provide the basis for vertical hierarchical structures, are less important factors in terms of their effect on communication style.

In all situations, Japanese people form hierarchical interpersonal relations (Nakane, 1970). Besides fixed hierarchical structures such as the relationship between parents and children, there are various kinds of interpersonal hierarchical structures which are changeable depending on the situation. The ability to determine one's changeable vertical relationships is natural and automatic (Nakane, 1970, 1978). In spite of this, a Japanese person who has lower status in an interpersonal relationship does not feel at a disadvantage. Condon (1984) stated that

It is not a matter of who is more famous or powerful. It is a matter of acknowledging one's proper place in a system that helps to maintain reasonably harmonious human relationships in a crowded land. (p. 22)

In other words, for the Japanese, awareness of status, either higher or lower, provides each person in an interpersonal relationship with a sense of security and determines the communication style to be used with the other person (Condon, 1984). 
The awareness of place allows a lower status person to make his or her requests in a manner appropriate or relevant to the relationship. Such appropriate or relevant expressions used by a lower status person are, for example, roundabout or humble. Because Japanese use less straightforward expressions in order to have a harmonious relationship (Ramsey, 1985), when a lower status person uses roundabout or humble expressions with the higher status person, the lower status person feels safe rationalizing or justifying his or her needs.

Brown and Levinson (1987) noted that the Japanese use more humble forms of politeness than U.S. people. They stated that these forms of politeness included giving the other person the freedom to decide. Also, a lower status person's presentation of reasons for a request gives a higher status person the feeling that he or she is in charge of the situation and has a free choice (Kipnis \& Schmidt, 1984). In this way, Falbo (1977a) stated that reasoning is associated with social skills and that those people who conform to group pressure tend to use this strategy.

In contrast, U.S. people try to minimize the perceived distance between people in hierarchial relationships. This distance is minimized, for example, by using relatively informal verbal forms of communication (Stewart, 1971). In addition, people in weak positions often use neutral, which are neither direct nor indirect, compliance-gaining 
strategies, such as an exchange of benefits or bargaining (e.g., Howard, Blumstein, \& Schwartz, 1986; Kipnis, Schmidt, \& Wilkinson, 1980). Another term for exchange of benefits is promising. Neuliep and Hazleton (1985) used this term in their study, which confirmed that U.S. people often use these compliance-gaining strategies. Although actual differences in power exist between lower and higher status people, these strategies may be able to fill the psychological gap (Howard et al., 1986). Because U.S. people value egalitarian relationships (e.g., stewart, 1971; Suzuki, 1991), they seem to use bargaining to sustain a psychologically egalitarian relationship and to avoid a power imbalance (Howard. et al., 1986). Neuliep and Hazleton (1985), in their study of compliance-gaining strategies selected by Japanese and U.S. people, stated trading as a means of bargaining is relatively common in the U.S.A. for the purpose of compliance-gaining. In addition, their study found that U.S. people used promises more as a means of exchange of benefit than Japanese people did. The foregoing discussion suggests that certain compliance-gaining strategies are used differently depending upon cultural orientations. The previous section discussed compliance-gaining strategies in terms of classifications: indirect as ingratiation, direct as assertion, and neutral, which are neither direct nor indirect, as rationalization or exchange of benefits. For testing the differences in 
compliance-gaining strategies between cultures as a whole, the neutral compliance-gaining strategies were used. Rationalization was used to describe the way in which the Japanese gain compliance, and exchange of benefits was used to describe the way in which U.S. people gain compliance. Accordingly, the following hypotheses were proposed.

H1: Japanese lower status people who are in shortterm, task-oriented relationships will use more rationalization compliance-gaining strategies than U.S. lower status people who are in short-term, task-oriented relationships.

H2: U.S. lower status people who are in short-term, task-oriented relationships will use more exchange of benefits compliance-gaining strategies than Japanese lower status people who are in short-term, task-oriented relationships.

GENDER DIFFERENCES IN COMPLIANCE-GAINING STRATEGIES

Although some studies have reported that women and men use similar compliance-gaining strategies at the managerial level (Harper \& Hirokawa, 1988; Hirokawa, Mickey, \& Miura, 1991), most of our everyday life is affected by gender role expectations. Such gender-based expectations function when people try to gain compliance from others. In the U.S.A., Schlueter, Barge, and Blankenship (1990) found 
significant differences in the selection of strategies between lower-level male and female managers. In Japan, Smith (1992) discussed the conflicts of women who are in controlling positions of authority but who use powerless language. It is assumed that lower status women use different behaviors than lower status men to gain compliance from higher status men. This section will compare Japanese culture and U.S. culture in terms of the social expectations of each gender and examine how they affect lower status people's compliance-gaining strategies and the intercultural aspects of gender differences.

\section{Stereotypes}

The processes of socialization and acculturation influence people to perceive different characteristics as desirable, depending on one's sex. According to a stereotyped view present in many cultures, men "should be" competitive and independent, while women "should be" supportive, submissive, and dependent (e.g., Broverman, Vogel, Broverman, Clarkson, \& Rosenkrantz, 1972; Falbo, 1977b). Harman, Klopf, and Ishii (1990) compared the Japanese and U.S. people's verbal aggression and concluded that gender based expectations were present in both Japanese and U.S. culture. Harman et al. (1990) stated that Men, the stereotypes infer, are more active, adventurous, ambitious, competitive, dominant, and aggressive than women, who, on the other hand, are sensitive to feelings, gentle, neat, quiet, 
tactful, talkative, and religious the stereotypes imply [sic]. (p. 1130)

This sociocultural influence leads men and women in both cultures to select different, yet the most effective, compliance-gaining strategies in their everyday behavior.

An expectation of the use of particular compliancegaining strategies by males and females is often described in terms of opposites. For example, unfriendly or friendly (Burgoon, Dillard, \& Doran, 1983) and direct or indirect strategies (Johnson, 1976) are used by males or females, respectively. Burgoon et al.'s (1983) study of gender-based expectations in language intensity showed that when a woman used aggressive language which is culturally acceptable for men, she was penalized. On the other hand, when a man used low intensity language which is culturally acceptable for women, he was perceived as weak and less successful.

Johnson (1976) noted that women were expected to use indirect power. She stated that there are strong sanctions against women using direct interpersonal power. Her study showed that if a woman used direct interpersonal power, which is culturally acceptable for men, she would be interpreted as "pushy, overbearing, unfeminine, and/or castrating" (p. 101). Broverman, Vogel, Broverman, Clarkson, and Rosenkrantz (1972) found that males could use "feminine characteristics [such as indirect interpersonal power]" but females were not allowed to show "masculine characteristics." Although these studies have been done in 
the U.S.A., they are also applicable to Japanese culture, which has even stronger traditional sex-role orientation (Lebra, 1984).

\section{Ingratiation Strategies and Women}

In general if women meet the expectations of genderbased stereotypes, they contribute to smooth social interaction, while violation of these expectations causes ineffective persuasion (e.g., Burgoon, Dillard, \& Doran, 1983). Therefore, in order for women to maintain relationships and, at the same time, gain favorable outcomes, they communicate through effective gender-based strategies, for example, helplessness, hinting, nagging, (Johnson, 1976), manipulation such as flattering and seducing, and supplication such as pleading (Howard, Blumstein, \& Schwartz, 1986) and crying (Falbo, 1977b). These indirect strategies are used in ongoing intimate relationships (Howard et al., 1986).

In contrast to personal relationships, task-oriented relationships such as work or education require that women use different indirect strategies, such as rationalization (Schermerhorn \& Bond, 1991) and charm, compliments, and ingratiation (DuBrin, 1991; Schmidt \& Kipnis, 1987) . Although seemingly weak, indirect interpersonal power can be effective and appropriate especially when it is used over the short-term (Johnson, 1976). 
Because socially approved gender-based behavior is more accepted, people feel more favorable toward women who use indirect strategies. Therefore, when a woman takes advantage of indirect strategies, she has a greater chance of gaining compliance without the other person becoming aware that he or she has been controlled (Johnson, 1976). Such strategies might be classified as ingratiation. Ingratiation was studied extensively by Jones (1964) who stated that

The term ingratiation...refers to a class of strategic behaviors illicitly [sic] designed to influence a particular other person concerning the attractiveness of one's personal qualities. (p. 11)

While Jones included compliments as ingratiation, Kipnis, Schmidt, and Wilkinson (1980) included humbleness in ingratiation when they researched upward compliance-gaining strategies.

In general, a lower status person trying to gain compliance from a higher status person generally requires a show of humbleness. These attitudes are typical in a culture which emphasizes vertical hierarchical structure in which women have lower status than men. Women are raised to be feminine (Lebra, 1984), which means to be humble in Japanese culture; therefore, humility becomes a component of their communication style. It is said that because Japanese women show humility in much of their usual communication, they are humble whether they are trying to gain compliance 
or not.

In the U.S.A., relative to Japan, women have been taught to be individualistic since childhood (Stewart, 1971), and they value egalitarianism (Suzuki, 1991) rather than humility. Suzuki (1991) stated that a U.S. woman chose to be a "person" as the first role rather than to be a "woman." Compared with Japanese women who behave more or less humbly because this is expected of women in any situation, U.S. women may select certain situations in which to be humble as a communication strategy. Suzuki (1991) stated that in an ideal form, U.S. women are treated according to their effort and ability within the context of a culture that values equal opportunity. In this way, when compared with Japanese women, U.S. women's use of politeness as ingratiation is more likely to be seen as a conscious effort, rather than simply a culturally based expectation.

Holtgraves and Yang (1992) found that U.S. people's use of politeness, including being humble, increased along with an increased relationship distance. An increase of politeness may also be associated with U.S. people's consciousness of the way in which they think they are being perceived in interpersonal relationships (Holtgraves \& Yang, 1992). It is, therefore, speculated that because of this U.S. women increase their level of politeness when trying to gain compliance from a higher status person. The use of compliments is another component of 
ingratiation strategy in which a person exchanges a desirable outcome by showing respect, thus making the other person feel good (Jones, 1964). A lower status person using compliments, such as showing respect to a higher status person, emphasizes the existing power structure in a given interpersonal relationship (Jones, 1964). Therefore, using compliments in a task-oriented relationship has hierarchical implications and serves to maintain the status differences between two people (Jones, 1964). Although using compliments functions to keep power relationships distant, the ingratiator's purpose is to minimize the psychological power distance in a relationship (Jones, 1964). This minimization of a relationship distance may be perceived as an effort to communicate, which is valued highly in U.S. culture.

In the U.S.A., compliments are used frequently and with wide acceptance (Barnlund \& Araki, 1985). Compliments can be defined in different ways. Barnlund and Araki (1985) differentiated compliments and flattering by defining compliments as "authentic expressions of admiration without manipulative intent" (p. 12). They added that "to the Japanese, 'Sanji [compliments]' was also felt to be an honest expression of praise..." (p. 12). Barnlund and Araki (1985) continued that "'Oseji [flattering],' on the other hand, might be honest or not, but could be used simply to promote conversation or more harmonious relations" (p. 12). 
However, it is assumed that when compliments are used to gain compliance, they have a manipulative function. In this way, both compliments and flattery can be included in ingratiation as "making the other person feel important" (Kipnis, Schmidt, \& Wilkinson, 1980, p. 447). Although sometimes ingratiation has negative connotations, schmidt and Kipnis (1987) accepted ingratiation simply as an active communication strategy in the U.S.A. They demonstrated that women who use ingratiation for persuasion were evaluated more favorably in the work place.

In contrast to its use in the U.S.A., the use of compliments as ingratiation may be ineffective in Japan, where people value hierarchically determined communication styles. In their cross-cultural study of compliments in Japan and the U.S., Barnlund and Araki (1985) showed that the Japanese used fewer verbal compliments than U.S. people. When the Japanese do use compliments, rather than doing so directly, they do so indirectly, using a third party (Barnlund \& Araki, 1985) which is perceived as being more pleasing (Jones, 1964). The Japanese do this in order to avoid the perception of insincerity. Because receiving compliments is not readily accepted by a listener in Japanese culture, the listener may become defensive and suspicious of the speaker's intent. Compliments received through a third person, however, remove any suspicions of that intent (Wortman \& Linsenmeier, 1977). 
Also, giving compliments may involve developing an exchange condition (Dienesch \& Liden, 1986; Liden \& Mitchell, 1988); therefore, for a lower status person to give compliments may imply that he or she does not respect a hierarchical relationship. Liden and Mitchell (1988) stated that "[compliments] focus on making the target feel good so that a favorable impression of an ingratiator will be made" (p. 579). Japanese culture, which emphasizes being humble rather than achieving personal goals, may perceive active ingratiating negatively. Jones (1964) stated that

the upward communication of flattering compliments seems to violate the role prescriptions governing the behavior of persons low in power. It is presumptuous for an underling implicitly to claim the capacity to appraise a superior. ( $p$. 93)

Jones demonstrated that a higher status person is more likely to give compliments to a lower status person (e.g., "you are an excellent person to have on the job") than a lower status person is to give them to a higher status person (e.g., "you are an excellent boss"). The underlying assumption is that a lower status person is not in the position in to evaluate a higher status person. Therefore lower status people using compliments in order to gain compliance may be less successful in Japan.

Thus, in this comparison between Japanese women and U.S. women, and their use of indirect compliance-gaining strategy in an interpersonal interaction, the following hypothesis is proposed: 
H3: U.S. lower status females who are in short-term, task-oriented relationships will use more ingratiation compliance-gaining strategies than Japanese lower status females who are in short-term, task-oriented relationships.

\section{Assertion Strategies and Men}

Gender based compliance-gaining strategies used by males include, for example, assertion (Kipnis, schmidt, \& Wilkinson, 1980). According to Webster's Third New International Dictionary (1986), to assert is "to state or affirm positively, assuredly, plainly, or strongly; to demonstrate the existence of; and to demand and compel recognition of" (p. 131). Although males use not only direct compliance-gaining strategies but indirect strategies as well (Johnson, 1976), males who conform to gender-based expectations are more persuasive than males who do not (Burgoon, Dillard, \& Doran, 1983). Even males who have lower status use assertion strategies because of genderbased expectations: Assertion is a masculine stereotype (Gaa, Liberman, \& Edwards, 1979). In terms of the genderbased expectations, lower status males are relatively less afraid of facing a situation and trying to gain compliance from a higher status person than lower status females. Such compliance-gaining strategies include confrontation, setting time deadlines, and insistence (Kipnis et al., 1980). Confrontation is one form of assertion compliance- 
gaining strategy which appears to be associated with U.S. culture, where value is placed on being egalitarian and individualistic, where an individual makes an effort for his or her self-achievement (e.g., Hofstede, 1984 ; Stewart, 1971). Nadler, Keeshan Nadler, and Broome (1985) stated that "for North Americans, individuals are expected to stand up for their rights, and this often involves open confrontation" (p. 109). Hattori's (1992) study, which compared cross-cultural confrontation differences between the U.S.A. and Japan, mentions this, showing that in a casual friend relationship U.S. people used more direct confrontation than Japanese.

In contrast to the relatively individualistic and egalitarian culture of the U.S.A., Japanese culture has a clear vertical hierarchical structure and emphasis on group harmony which tends to avoid direct confrontation (Lebra, 1976). Japanese people may show their feelings or thoughts through nonverbal communication such as eye contact in order to avoid direct confrontation (Doi, 1973). Brown and Levinson (1987) stated that indirectness leads another person to interpret the meaning. Thus, relative to U.S. lower status males, Japanese lower status males may use more subtle assertion strategies.

Studies have shown that lower status males meet not only gender expectations but status expectation as well. Burgoon, Dillard, and Doran (1983) stated that lower status 
people are expected to use such low intensity language as polite forms. The use of polite language may solve the conflict between the expectation of male assertiveness and the need to show respect towards a higher status person, particularly when making a request. Brown and Levinson (1987) predicted that lower status people use more polite forms than higher status people. Polite forms such as "would you...?" or "could you...?" can be added with direct ordering or insisting words, and a form of "may I...?" can compensate for statements that could be seen as aggressive. In Japan, high rank is associated with being politely addressed (Jorden, 1987). Therefore, not surprisingly, lower status people use honorifics or other forms of politeness, of which there are many, to make direct strategies sound less aggressive when gaining compliance from higher status people.

Insistence is another assertion strategy. When using insistence, a lower status male may repeat or reinforce his request without aggressive behavior. Burgoon and Miller's (1990) study found that once information was processed by the listener, repetition was an important factor for changing the other person's behavior. While repetition may work in the U.S.A., it may not be effective in Japan because, according to Hall (1976), the Japanese use less verbal communication than U.S. people. In Japanese culture, less verbalization is valued 
(Kindaichi, 1975). The valued speech patterns in Japan are, for example, silence, conciseness, and lesser degrees of repetition, which are associated with men (Kindaichi, 1975; Shibamoto, 1985). Japanese males' gender-based expectation regarding verbal communication is that of being less talkative (Kindaichi, 1975). Therefore it is assumed that in order for Japanese males to try to gain compliance from other people, they would not waste words by repeating themselves.

A cross-cultural study comparing the assertiveness of Japanese and U.S. students was done by Thompson, Ishii, and Klopf (1990): Their definition of assertiveness included an ability to make requests. Their finding was, not surprisingly, that U.S. males were more assertive than Japanese males. The researchers did not interpret their findings, but it was implied that the lesser degree of Japanese male assertiveness was due to greater concern for harmonious relationships. This implication is seen in their statement that "Japanese are more apprehensive about interacting orally with others [and] Japanese are more reticent than the American" (p. 830). This importance placed on harmonious relationships is also described by Burgoon, Dillard, Doran, and Miller (1982). They researched cross-cultural persuasiveness and stated that "persuasive behavior is not 'owned' by the individual [in Japan]" (p. 97). This emphasis on harmony leads to a decrease in the 
necessity for asserting one's own requests.

Assertiveness is used by lower status as well as higher status people (Kipnis, Schmidt, \& Wilkinson, 1980). In addition, cultural background affects the use of assertion to gain compliance. The hypothesis proposed in relation to the cultural differences in the use of assertion by males is:

H4: U.S. lower status males who are in short-term, task-oriented relationships will use more assertion compliance-gaining strategies than Japanese lower status males who are in short-term, task-oriented relationships. 
CHAPTER III

METHOD

This chapter describes the research methods used for examining the selection of compliance-gaining strategies used by people of both sexes from both Japanese and U.S. culture. This chapter presents the research design, sample, instruments, procedures, and statistical methods.

\section{RESEARCH DESIGN}

Schermerhorn and Bond (1991) researched the intercultural differences between U.S. and Chinese upward compliance-gaining strategies in an organizational setting. Their research was a comparison between Hong Kong Chinese and U.S. peoples and included both upward and downward compliance-gaining strategies. Instruments composed by the researchers were short scenarios and questions based on previous research by Kipnis, schmidt, and wilkinson (1980). This study closely replicated the method used by Schermerhorn and Bond (1991), with an exclusive focus on upward influence tactics. Prior to conducting an actual survey, a hypothetical scenario was composed by the 
researcher and question items were taken from Kipnis, Schmidt, and Wilkinson's (1980) study for the pilot study.

\section{Theoretical Model}

This research was expected to reveal relationships between the culture and/or sex of the subjects and the selection of compliance-gaining strategies with the intervening variable of the status of the requester. This is illustrated in Figure 1: How the subjects' culture and/or sex causes the selection of different kinds of compliance-gaining strategies in terms of having lower status.

Each concept (culture, sex, and upward compliancegaining strategies) and the intervening variable of lower status used for this study were defined as follows:

1. Culture was defined according to its values, beliefs, and attitudes. The U.S.A. is known to be individualistic and egalitarian, with emphasis on the minimization of psychological distance in a hierarchy. Japan, on the other hand, is known to be collectivistic and relationships are organized according to a social hierarchical structure. In this study, cultures were operationally carried out and represented by U.S. students and Japanese students.

2. Gender was defined as the sociocultural expectations of behavior for males or females, including the expression 
of directness or indirectness as they were expected for males or females, respectively.

3. Upward compliance-gaining strategies were defined in terms of task-oriented relationships. Individuals who had lower status tried to influence in order to gain compliance from higher status people. The four most often used strategies identified by Kipnis, Schmidt, and Wilkinson (1980) were ingratiation, exchange of benefits, rationalization, and assertion. These strategies were operationalized by responses to questionnaire items adapted from Kipnis et al.'s (1980) study (see pp. 51-53).

4. Lower status was defined in this study as that of a regular status individual when contrasted with those in a position of leadership in a task-oriented relationship. students who were regular members of a class project were considered as lower status for this study.

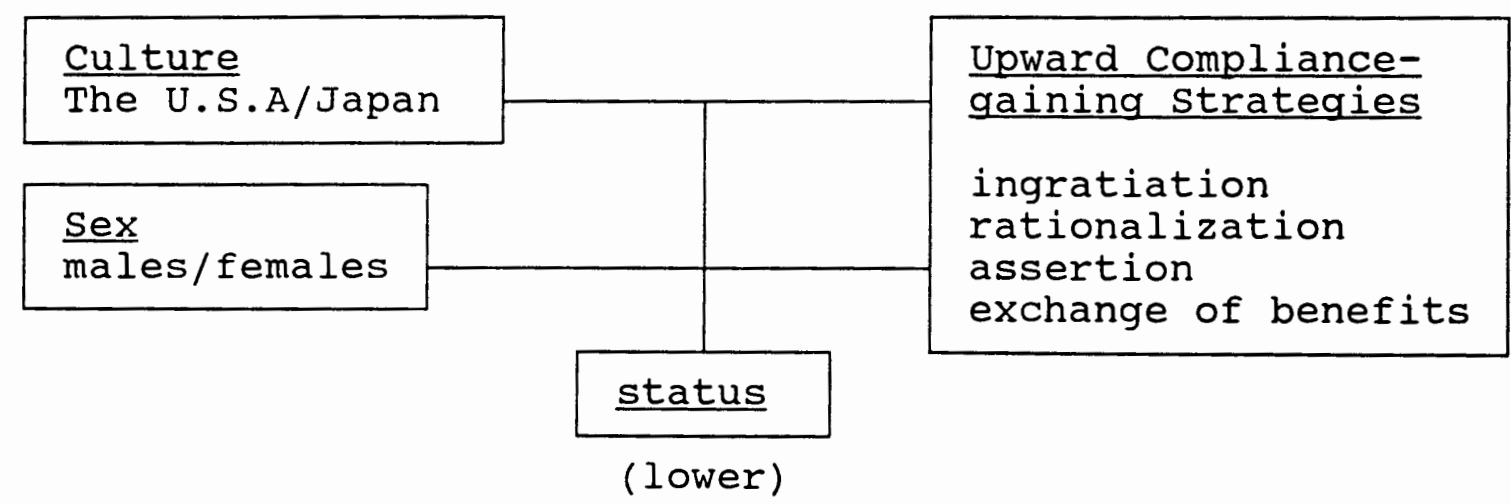

Figure 1. Relationship among the three variables, with status held constant. 
SAMPLE

\section{Sampling Frame}

The sampling frame was drawn from people who had already been exposed to both cultures and who had experience participating in task-oriented groups. Because the length of interaction can be a variable in the selection of a particular compliance-gaining strategy (DuBrin, 1991) and because the length of interaction in a group setting for business people varies according to each individual's experience, students were used as a sampling frame for this study. In addition, those students who are willing to be exposed to a different culture in school are more likely to have the chance to communicate with people from different cultures outside of school.

Students have the experience of short-term, taskoriented relationships such as classroom projects. These short-term, task-oriented group projects are also seen outside of school, as in, for example, a joint-venture business project. A task-oriented project group usually consists of a leader and regular group members, who are assumed to have lower status than the leader.

The sample for the U.S. students was drawn from those who have studied Japanese language and culture at U.S. colleges. Because of the language difficulty for U.S. students who might wish to enroll in Japanese schools 
(Jorden, 1991), there are few U.S. students in Japan (Soumucho Toukeikyoku, 1990). However, many colleges offer Japanese language classes in the U.S.A. (Jorden, 1991). It was assumed that U.S. students who had studied Japanese language and culture for at least one term would have been exposed somewhat to Japanese culture.

The sample for the. Japanese students was from those who have studied in the U.S.A., rather than those who have studied in Japan. Japanese students who study in the U.S.A. meet the requirements for this study: Not only have they been exposed to an intercultural environment, but they also have a greater chance to participate in U.S. classroom projects, which are rare in Japanese colleges (Watanabe, 1990).

In order to avoid subjects who had become overly assimilated to the other culture, the subjects selected were limited to those whose length of stay in their new culture was less than three years. This applied not only to Japanese students who studied in the U.S.A., but also U.S. students who might have lived in Japan.

\section{Subjects}

The subjects for this study were U.S. students (59 male and 55 female) who have studied Japanese language, and Japanese students (65 male and 100 female) who have enrolled in colleges in Portland and Salem. The majority of the U.S. 
subjects were drawn from Portland state University and Portland Community college. The majority of Japanese students were drawn from the Tokyo International University of America, the branch of the Japanese university located in Salem, Oregon, and students from Hyogo, Japan, who attended

a special program at Portland State University. A small number of Japanese students who independently attended U.S. colleges also participated in the survey.

\section{INSTRUMENTS}

\section{Scenario}

A hypothetical scenario was composed by the researcher (see appendices $\mathrm{E} \& \mathrm{~F}$ ). The hypothetical situation involved a classroom project involving a group with a leader. In order to gain a more realistic response, the hypothetical project was set in a classroom rather than a business setting. Also, in order to create a clear power hierarchy within the hypothetical group, the leader was designated by the instructor of the class.

The scenario was identical for the Japanese and U.S. subjects except for the opening remarks and the leader's nationality. The leader in the scenario was either a 30 year-old U.S. or Japanese male. The leader's nationality was the same as the subjects' nationality in order to obtain a more natural response. A male leader was chosen because 
the pilot study showed that the experience of having a male leader was more common, and the age of the leader was set at 30 because Portland State University's average student age is 29 (Portland State University, 1992).

\section{Variables}

Twenty-one question items were taken from Kipnis, Schmidt, and Wilkinson's (1980) study (see appendix G). Kipnis et al. (1980) studied influential tactics for gaining compliance from supervisors, subordinates, and co-workers. They first asked their subjects to write an essay describing the way they influenced either their bosses, co-workers, or subordinates. Out of 165 subjects, a total of 370 influence tactics were identified, and they were classified into 14 categories. In the next stage, Kipnis et al. (1980) developed 58 question items based on the 370 influential tactics. The 58 question items were administered to 754 subjects. These question items were factor analyzed and resulted in eight categories: assertiveness, ingratiation, rationality, sanction, exchange of benefits, upward appeal, blocking, and coalitions.

Two of the categories, sanctions, such as "give no salary increase or prevented the person from getting a pay raise," and blocking, such as "threatened to notify an outside agency if he or she did not give in to my request," were considered to be unapplicable for the current study. 
Therefore, sanctions and blocking were excluded from this study. Furthermore, Schreishiem and Hinkin (1990) used 27 out of 58 items in their article "Influence Tactics Used by Subordinates: A Theoretical and Empirical Analysis and Refinement of the Kipnis, Schmidt, and Wilkinson subscales." Thus, 27 items from six categories (ingratiation, rationality, assertiveness, exchange of benefits, upward appeal, and coalition) appeared to be used by lower status people. Because coalition strategies were included in only two items, that category was excluded from this study. In addition, upward appeal strategies got a low score in the pilot study, so they also were excluded. Thus, for this study, the 21 question items from the four categories, ingratiation, rationality, assertiveness, exchange of benefits, were retained.

For the purpose of this study, the words rationalization and assertion were used instead of rationality and assertiveness which Kipnis et al (1980) used. According to Webster's Third New International Dictionary (1986), rationality is defined as "the quality or state of being rational" ( $p$. 1885), while rationalization is defined as "the act, process, or result of rationalizing" (p. 1885). Because this study focused on communication styles in different cultures rather than the quality or condition of those behaviors, the word rationalization as an action was more suitable. Similarly, the word assertion as 
"the act of asserting or something that is asserted" (Webster's Third New International Dictionary, 1986, p. 131) was used rather than assertiveness, which is defined as "the quality or state of being assertive" (p. 131).

The tense of the sentences for the question items (the original statements were past tense) and the wording of some question items was changed to make them more suitable to the current hypothetical scenario and subjects. The words "the leader" were used instead of the pronouns "he" or "she," which were used in the original statement. To make the statement clearer, the phrase "changing my task" was used in some of the question items.

Rationalization. This category included four question items (Q3, Q8, Q12, and Q17): (Q3) I would explain the reasons for my request; (Q8) I would use logical reasoning to convince the leader; (Q12) I would write down a detailed plan that justified my ideas; and (Q17) I would present the leader with information in support of my point of view. In Q8, the phrase "logical reasoning" was used instead of the word "logic," which was used in the original statement. Exchange of benefits. This category included five question items (Q2, Q5, Q9, Q15, and Q20): (Q2) I would offer help to the leader if the leader would agree to change my task; (Q5) I would offer an exchange (e.g., if you change my task, I will do something for you); (Q9) I would remind the leader of past favors that I have done for him; (Q15) I 
would offer to make a personal sacrifice if the leader would do what I want (e.g., work late, work harder, do his share of the work, etc); and (Q20) I would do personal favors for the leader.

The word "change" was used instead of "do" which was used in the original statement in 22 and Q5. For example, the original statement of $Q 5$ "... if you do this for me..." was changed to "... if you change my task...". In 22 , the wording was altered to be more suitable for the current scenario: The original statement was "offered to help if he/she would do what I wanted."

Ingratiation. This category included six items ( $Q 1$, Q6, Q10, Q14, Q18, and Q21: (Q1) Before asking the leader to change my task, I would make the leader feel good about me; (Q6) before asking about changing my task, I would act in a friendly manner to the leader; (Q10) I would wait until the leader appeared in a receptive mood before asking; (Q14) I would make the leader feel important by saying statements such as, "you are the only one with the ability to handle this group"; ( $(18)$ I would show my sympathy about the added problems that my request caused; and (Q21) I would act very humbly to the leader while making my request.

The wording was changed in Q14: The original statement was "Made him or her feel important ('only you have the brains, talent to do this')." In Q18, the phrase "show my sympathy" was used instead of the word "sympathize," which 
was used in the original statement.

Assertion. This category included six question items (Q4, Q7, Q11, Q13, Q16, and Q19): (Q4) I would become a nuisance (keep bugging the leader until he did what I wanted); (Q7) I would point out that there are rules which require the leader to comply with my request; (Q11) I would set a time deadine for the leader to do what I asked; (Q13) I would express my anger verbally; (Q16) I would have a showdown in which I would confront the leader face-to-face; and (Q19) I would repeatedly remind the leader about my request.

For $Q 7$ the words "with my request" were added to make the statement clearer. For $Q 19$ the words "my request" were changed from the original statement "... what I wanted...."

While Kipnis, Schmidt, and Wilkinson (1980) used a five-point Likert-type scale for their study, in order to avoid the tendency for Japanese subjects to select the midpoint of a scale range (Sugita, 1992), a six-point (1 = almost never, to $6=$ almost always) was used. A six-point scale was expected to show greater differentiation than a five-point scale.

other questions. Followed by the 21 questions, four questions regarding group projects were asked: (1) How realistic do you think the scenario is; (2) do you think the group leader's age would influence your communication style; (3) do you think the group leader's gender would influence 
your communication style; and (4) have you had any group projects in any class before?

Individual subjects' demographic questions such as age, sex, nationality, length of living in the U.S.A. or Japan, and length of studying Japanese language for U.S. subjects, were also asked.

\section{PROCEDURES}

\section{Translation}

The original research packet was written in English and translated into Japanese for the Japanese subjects by the researcher. It was assumed that this would make reading of the scenario easier for the Japanese subjects (Sugita, 1992). It also may provide a more accurate and uniformed reading than English, since the ability of Japanese subjects to read English varies (Sugita, 1992).

The translation was back-translated by two Japanese people who did not know the research topic. One person holds an M.A. from the University of Oregon and the other person is currently teaching Japanese language at willamette University in salem, oregon. The two back-translations were evaluated independently. The wording used by the two backtranslators was checked by native English speakers to make sure the contents were the same. Double checking was done by a Japanese Ph.D. Candidate at Portland State University. 
The final review was done by a native-speaking professor of Japanese who is currently teaching Japanese in the Foreign Language Department at Portland State University.

\section{Pilot study}

The pilot study was conducted with ten U.S. students who had studied Japanese language and nine Japanese students whose major varied but whose length of stay in the U.S.A. was less than three years. The purpose of the pilot study was to check whether or not the content of the hypothetical scenario was appropriate for the subjects, and whether the length of the scenario was acceptable. It was also to check whether the translation was written in a colloquial style appropriate for young Japanese subjects. Based on their suggestions, some wording in the scenario was changed without changing the content.

A couple of subjects commented that the hypothetical scenario should be shorter. While many subjects did not pay attention to the leader's nationality and age in the hypothetical scenario, a suggestion was given that the leader should be older. However, in order to provide enough information to both U.S. and Japanese subjects, the length of the scenario remained the same. Regarding the suggestion about the age of the leader, because of an increasing number of young leaders nowadays, it was decided that the age of the leader in the scenario would remain the same. 
The pilot study showed that both the U.S. subjects and the Japanese subjects had more experience with male leaders than female leaders, although this was true with the U.S. subjects to a lesser degree. Accordingly, this study used a male leader to test the compliance-gaining strategies of lower status people in the hypothetical scenario.

The question items were taken from Kipnis, Schmidt, and Wilkinson (1980), with changes in tense and some wording to make the language natural, and adapted to the hypothetical scenario. Pilot study subjects commented about the question items, saying, for example, that they were too generally stated, that some questions were redundant, and that the wording in some places was not specific. However, to maintain continuity with the content with the kipnis et al.'s (1980) study, the question items were not modified. Suggestions relating to the rating method were, for example, that a five-point scale be used rather than a sixpoint scale, although most subjects did not express a preference. However, because of the Japanese tendency to rate at mid points, the rating scale remained a six-point scale. Another suggestion about rating was that numbers should be circled rather than written down. In order to avoid ambiguous answers (circling between numbers), the rating scales remained unchanged.

The pilot study showed that the influential compliancegaining strategy most likely to be used was rationalization- 
-"I would explain reasons for my request"--with a mean score of 5.68 and standard deviation of 0.75 . The least used compliance-gaining strategy was the assertion--"I would become a nuisance; keep bugging the leader until he/she did what I wanted"--with a mean score of 1.42 and standard deviation of 0.90 .

\section{Data collection}

A research packet which consisted of an informed consent sheet (see appendix A), a cover letter for the subject (see appendix B), a demographic information sheet (see appendices $C \& D$ ), a short scenario (see appendices E\& F), and 21 questions (see appendix G) was administered in spring term, 1993. Prior to the administration of this questionnaire, a telephone inquiry was made or a cover letter was sent (see appendices $H \& I$ ) to the instructors of the students who were to take part in this research.

For the majority of the subjects, the research packet was distributed and administered a few minutes before their class was over. Some instructors allowed the researcher to conduct the survey at the beginning of class. A few students participated independently, at their convenience. The subjects were informed that participation was voluntary. When the subjects agreed to participate in the survey, they were asked to sign two copies of an informed consent: one for the subject and one for the researcher. 
The subjects were asked to complete the questionnaire anonymously and were informed of their freedom to withdraw at any time. For the Japanese subjects, the researcher explained the research packet in Japanese.

Following the scenario, 21 question items with a sixpoint Likert-type scale was given to the subjects to answer. Scores for each question item were totaled. Higher scores show frequent use of a compliance-gaining strategy.

\section{STATISTICAL METHODS}

The 21 question items for compliance-gaining strategies were categorized according to Kipnis, Schmidt, and Wilkinson (1980): rationality, exchange of benefits, ingratiation, and assertiveness. Rationality and exchange of benefits were used to test the hypotheses about cultural differences. Hypothesis one is that Japanese lower status people who are in short-term, task-oriented relationships will use rationalization compliance-gaining strategies more than U.S. lower status people who are in short-term, task-oriented relationships. Hypothesis two is that U.S. lower status people who are in a short-term, task-oriented relationships will use more exchange of benefits compliance-gaining strategies than Japanese lower status people who are in short-term, task-oriented relationships.

Ingratiation and assertiveness were used to test the 
hypotheses about gender expectation. Hypothesis three is that U.S. lower status females who are in a short-term, task-oriented relationship will use more ingratiation compliance-gaining strategies than Japanese lower status females who are in short-term, task-oriented relationships, and hypothesis four is that U.S. lower status males who are in short-term, task-oriented relationships will use more assertion compliance-gaining strategies than Japanese lower status males who are in short-term, task-oriented relationships.

Multivariate analysis of variance (MANOVA) with independent groups was used for testing the hypotheses. Subsequently, a follow-up t-test was performed for U.S. and Japanese female groups and U.S. and Japanese male groups. 
CHAPTER IV

RESULTS

This chapter presents the results of the data analysis. The statistical Package for the Social sciences (SPSSX) was used in statistical analysis for this study.

\section{SAMPLE CHARACTERISTICS}

Responses and subjects for This study

The subjects were selected from Portland state University, Portland Community college, Tokyo International University of America, other colleges in the Portland, oregon, and Vancouver, Washington, and through individual contacts. Three hundred sixty two subjects, $117 \mathrm{U} . \mathrm{S}$. subjects, 178 Japanese subjects, and 67 of other nationalities, responded: a response rate of $94 \%$. For the purpose of this study, which was to compare the U.S. and Japan, only U.S. and Japanese responses were used for analysis. In order to have a more natural measurement for the subjects' communication strategies, the U.S. and Japanese subjects who had lived in either country over three years were discarded from the data analysis. Therefore, 114 
U.S. (59 male and 55 female) and 165 Japanese (65 male and 100 female) responses were used for the data analysis.

\section{Subjects' Characteristics}

Average age for the U.S. subjects was 27 and for the Japanese, 20. All of the U.S. subjects had studied Japanese language and their average length of studying Japanese was 28.3 months. Most of the Japanese subjects belonged to one of two large groups from two different colleges: 101 subjects had studied at Tokyo International University of America, in Salem, Oregon, and 32 subjects (all female) were from Hyogo, Japan, and had studied at Portland State University.

of all the U.S. subjects, 53 subjects had lived in or visited Japan for an average of six months. The Japanese subjects' average length of stay in the U.S.A. Was five months.

\section{RELIABILITY}

\section{Evaluation of the Scenario and Group Projects}

As to whether the subjects had experience in group projects at school, more U.S. subjects ( $84.1 \%$ ) had experienced group projects at school than Japanese subjects (55\%). The rating for how realistic the survey scenario was measured on a six point Likert-type scale (1-not at all, to 
6-very much), and the results showed means of 4.33 for the U.S. subjects and 4.10 for the Japanese subjects. Regarding group projects in general, in a question about how much a leader's age would influence a subject's communication style, both U.S. and Japanese subjects rated high. Incidentally, both the U.S. and Japanese mean scores were 4.18 .

\section{Reliability}

The collective reliability coefficients (both U.S. and Japanese subjects) for the four compliance-gaining strategies were ingratiation (alpha $=.74$ ), exchange of benefits (alpha $=.69)$, rationalization $($ alpha $=.58)$, and assertion (alpha $=.72)$. A comparison was made with Kipnis, Schmidt, and Wilkinson's (1980) study. Ingratiation, exchange of benefits, and assertion showed similar reliability coefficients to Kipnis et al.'s (1980), while rationalization showed lower reliability than kipnis et al.'s (1980). Reliability coefficients for each compliancegaining strategy used by U.S. and Japanese subjects are shown in TABLE I (see pp. 51-53 for each scale's questions). 
TABLE I

RELIABILITY COEFFICIENTS FOR FOUR COMPLIANCE-GAINING STRATEGIES USED BY U.S. AND JAPANESE SUBJECTS

\begin{tabular}{lcc}
\hline & U.S. $(\underline{\mathrm{n}}=110)$ & Japan $(\underline{\underline{n}}=157)$ \\
\hline Ingratiation & .75 & .78 \\
Exchange of benefits & .72 & .68 \\
Rationalization & .45 & .57 \\
Assertion & .76 & .65 \\
\hline
\end{tabular}

Note. $\underline{\mathrm{n}}=$ Number of subjects

OVERALL STATISTICAL ANALYSIS

Descriptive Statistics

The grand means on a six-point likert-type scale indicated that both the U.S. and the Japanese subjects $(\underline{\mathbb{N}}=$ 279) used rationalization $(\underline{G M}=4.17)$ and ingratiation ( $\underline{G M}=$ 3.31) more often than exchange of benefits $(G M=2.23)$ and assertion $(\underline{G M}=2.58)$ to gain compliance. The means and standard deviations for the four compliance-gaining strategies by each culture are shown in TABLE II.

\section{Multivariate Analysis of Variance (MANOVA)}

Multivariate analysis of variance (MANOVA) for independent groups (Subject's culture $x$ Subject's sex) on ingratiation, exchange of benefits, rationalization, and assertion was performed. No significant differences were found in the culture by sex interaction. MANOVA revealed a significant effect for sex (Wilks $=.95, \underline{F}=3.35, \underline{p}<.05)$, 
and a significant effect for culture (Wilks $=.45, \underline{F}=$ $82.97, \underline{p}<.001)$. MANOVA revealed significant differences in survey responses between U.S. and Japanese subjects for all of the four compliance-gaining strategies: ingratiation $[\underline{F}(1,275)=26.00, \underline{p}<.001]$; exchange of benefits $[\underline{F}(1,275)$ $=9.57, \underline{\mathrm{p}}<.002]$; rationalization $[\underline{\mathrm{F}}(1,275)=73.42$, $\underline{\mathrm{p}}<.001] ;$ and assertion $[\underline{F}(1,275)=74.25, \underline{\mathrm{p}}<.001]$. MANOVA also revealed significant differences in sex for assertion only $[\underline{F}(1,275)=7.47, \underline{p}<.01]$. TABLE III shows means and standard deviations for assertion.

\section{TABLE II}

MEANS AND STANDARD DEVIATIONS FOR RATIONALIZATION, EXCHANGE OF BENEFITS, INGRATIATION, AND ASSERTION

$$
\text { U.S. }(\underline{n}=114) \text { Japanese }(\underline{n}=165)
$$

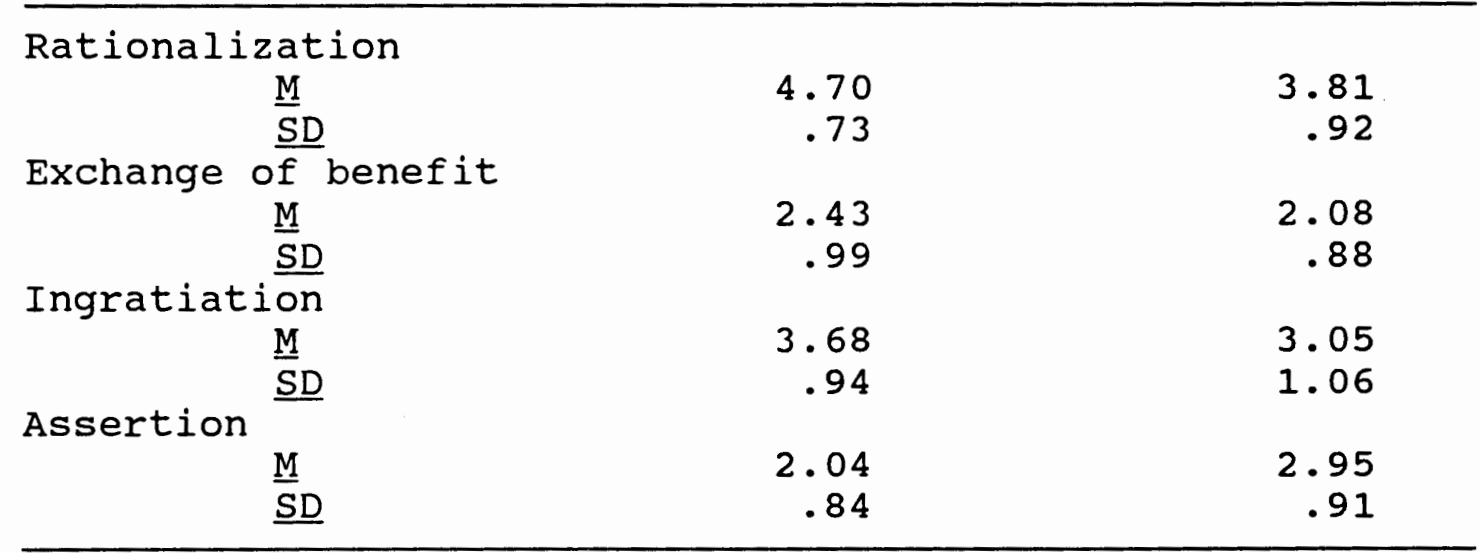

Note. $\underline{M}=$ Mean scores

$\underline{S D}=$ Standard deviations

$\underline{\underline{n}}=$ Number of subjects 
TABLE III

MEANS AND STANDARD DEVIATIONS FOR ASSERTION

\begin{tabular}{llc}
\hline & Means & Standard Deviations \\
\hline U.S. total $(\underline{\mathrm{n}}=114)$ & 2.04 & .84 \\
males $(\underline{\mathrm{n}}=59)$ & 2.19 & .89 \\
females $(\underline{\mathrm{n}}=55)$ & 1.88 & .77 \\
Japan total $(\underline{\mathrm{n}}=165)$ & 2.95 & .91 \\
males $(\underline{\mathrm{n}}=65)$ & 3.12 & .97 \\
females $(\underline{\mathrm{n}}=100)$ & 2.84 & .85 \\
\hline
\end{tabular}

Note. $\underline{n}=$ Number of subjects

TESTING HYPOTHESES

Based on the results of the previous MANOVA, the four hypotheses can now be examined.

\section{Hypothesis one}

"Japanese lower status people who are in short-term, task-oriented relationships will use more rationalization compliance-gaining strategies than U.S. lower status people who are in short-term, task-oriented relationships."

MANOVA revealed a significant difference based on culture for rationalization $[\underline{F}(1,275)=73.42, \underline{p}<.001]$. The means for U.S subjects $(\underline{n}=114)$ were 4.70 and Japanese subjects $(\underline{n}=165)$ were 3.81 . The results did not support hypothesis one. 
Hypothesis Two

"U.S. lower status people who are in short-term, taskoriented relationships will use more exchange of benefits compliance-gaining strategies than Japanese lower status people who are in short-term, task-oriented relationships." MANOVA revealed significant difference in culture for exchange of benefits $[\underline{F}(1,275)=9.57, \underline{p}<.002]$. The means of U.S. subjects $(\underline{n}=114)$ were 2.43 and the Japanese $(\underline{n}=$ 165) were 2.08. Therefore, the results supported hypothesis two.

Hypothesis Three

"U.S. lower status females who are in short-term, taskoriented relationships will use more ingratiation compliance-gaining strategies than Japanese females who are in short-term, task-oriented relationships"

A $t$-test was performed only on the females in each culture. The t-test revealed significant differences $[\underline{t}(153)=3.94, \underline{p}<.001]$ between the U.S. females $(\underline{n}=55)$ and the Japanese females $(\underline{n}=100)$ : The means and standard deviation are shown in TABLE IV. The hypothesis was supported.

\section{Hypothesis Four}

"U.S. lower status males who are in short-term, taskoriented relationships will use more assertion compliance- 
TABLE IV

MEANS AND STANDARD DEVIATIONS FOR INGRATIATION

STRATEGIES USED BY U.S. AND JAPANESE FEMALES

\begin{tabular}{lcc}
\hline & Means & Standard Deviations \\
\hline U.S. females $(\underline{\underline{n}}=55)$ & 3.74 & .98 \\
Japanese females $(\underline{\underline{n}}=100)$ & 3.08 & 1.01 \\
\hline
\end{tabular}

NOTE. $\underline{n}=$ Number of subjects

gaining strategies than Japanese lower status males who are in short-term, task-oriented relationships."

Previous MANOVA revealed significant differences for assertion in both culture and sex. A t-test was performed on only the males in each culture. The t-test revealed significant differences $[\underline{t}(122)=-5.58, \underline{p}<.001]$ between the U.S. males $(\underline{n}=59)$ and the Japanese males $(\underline{n}=65):$ The means and standard deviation are shown in TABLE V. The results did not support hypothesis four.

TABLE V

MEANS AND STANDARD DEVIATIONS FOR ASSERTION STRATEGIES USED BY U.S. AND JAPANESE MALES

\begin{tabular}{lll} 
& Means & Standard Deviations \\
\hline U.S. males $(\underline{\underline{n}}=59)$ & 2.19 & .89 \\
Japanese males $(\underline{\underline{n}}=65)$ & 3.12 & .97 \\
\hline
\end{tabular}

Note. $\underline{n}=$ Number of subjects 


\section{ADDITIONAL ANALYSIS}

In order to test whether Japanese subjects who had group experience used more rationalization compliancegaining strategies than Japanese subjects who had no group experience, a $t$-test was performed on the Japanese subjects only. No significant differences were found $[\underline{t}(158)=1.06$, n.s.].

To test whether the age of the U.S. subjects influenced how they responded to the question items, a correlation was performed on the U.S. subjects only. Ingratiation showed a negative significant correlation with age $[-.21, \underline{\mathrm{p}}<.05]$. No significant correlations were found for exchange of benefits, rationalization, or assertion. 
CHAPTER V

DISCUSSION

This chapter discusses the limitations of this study and the overall findings. Each hypothesis is also examined, and suggestions for future research are provided.

\section{LIMITATIONS}

The previous chapter showed the relationship between the results and the hypotheses. Two out of four hypotheses regarding exchange of benefits and ingratiation were supported. Two other hypotheses regarding rationalization and assertion were not supported. Furthermore, results from questions involving rationalization showed low reliability. Inconsistencies in the results illustrate possible limitations of this study. In addition to overall limitations present in any study, the cross-cultural nature of this research carries with it its own limitations.

\section{overall Limitations}

Based on the assumption that a classroom project in an educational setting and a business project in a work-place 
setting have similarities, such as the frequent use of short-term, task-oriented relationships, and a hierarchical structure in these relationships (a leader and group members or subordinates), the sample was taken from educational settings. However the question items which were taken from Kipnis, Schmidt, and Wilkinson's (1980) study focused on compliance-gaining strategies in work-place situations. The question items should be effective in profit-oriented organizations, such as business industries, while some question items might have confused subjects who did not have work experience

Although the results showed that both the U.S. and Japanese subjects indicated that the hypothetical scenario was highly realistic, the way the subjects perceived the leader was unknown. The survey should have asked directly whether the subject perceived a leader to have higher status than the rest of the group.

While Kipnis, Schmidt, and Wilkinson (1980) asked their subjects what they did in order to gain compliance, this study asked the subjects what they would do. This gap between facts and suppositions may have affected the subjects' responses. In other words subjects may have not replied consistently: The subjects who had experience in group projects may have replied according to what they did for some questions, while they may have replied what they would do for some other questions. The survey should have 
asked what they did, as Kipnis et al.'s (1980), and selected subjects who had experienced group projects.

Another problem was that some wording in the question items, which was almost the same as the original, was too general and ambiguous, and it might have caused some subjects to interpret the item in a way which differs from other subjects. While the questionnaire included an item to rate the realism of the scenario, it did not ask how realistic the questions were. The survey should also have included a question to rate the question items as well.

Lastly, while the purpose of using a six-point scale was to avoid Japanese tendency to rate a mid point (Sugita, 1992), using a six-point scale might not be reliable for these particular question items taken from kipnis, schmidt, and Wilkinson's (1980) study, in which a five-point scale was used.

\section{For the U.S. Subjects}

A researcher from a different culture conducting a survey in the U.S. may have influenced the subjects' perception of the language in the questionnaire. Although the question items were taken from the U.S. researchers' study (Kipnis, Schmidt, \& Wilkinson, 1980), some subjects commented that the wording was not natural English. This perception might have affected the U.S. subjects' responses to the questionnaire. 
Regarding the sample characteristics, a majority of the U.S. subjects who studied at Portland State University and Portland Community college may differ in socioeconomic class from a majority of the Japanese subjects who were enrolled in the private Japanese colleges and also studied in the U.S.A. These differences in social class between the U.S. and Japanese subjects might also have contributed to differences in the way they responded to the question items.

For the Japanese Subjects

A language problem might have occurred with the Japanese subjects also. Although the translation was carefully checked, there might be some unnatural wording for specific strategies in Japanese, wording which is unnatural to young Japanese subjects who have not experienced classroom group projects.

The question items were taken from U.S. perspectives on compliance-gaining strategies; therefore some question items might have been unfamiliar to the Japanese. The Japanese subjects might have been forced to rate some question items which were not in their usual communication styles.

Unlike the U.S. subjects, who were selected evenly from different Japanese language classrooms, a majority of the Japanese subjects were from only two Japanese colleges. The homogeneity of Japanese subjects might have had some affects 
on the survey.

\section{FINDINGS AND INTERPRETATION}

\section{Overall Findings}

This study proposed the research question "How do Japanese people and U.S. people who are in short-term, taskoriented relationships compare in their use of various tactics of upward influence?" Under the research question, four hypotheses were proposed corresponding to each of the compliance-gaining strategies: rationalization, exchange of benefits, ingratiation, and assertion, all of which were assumed to be used by lower status people. Rationalization and exchange of benefits were used to test two hypotheses regarding Japanese or U.S. culture as a whole, and ingratiation and assertion were used to test the other two hypotheses regarding gender in the different cultures.

The results indicated that group members who have not developed intimate relationships yet, who are in a shortterm, task-oriented situation, would select safer or relatively friendly compliance-gaining strategies instead of more risky ones. Accordingly, both U.S. and Japanese subjects used more rationalization and ingratiation to gain compliance than exchange of benefits or assertion. The results supported previous studies which showed the ways in which lower status people maintain relationships (e.g., 
Cohen, 1958; Tierney, 1989; Waldron, 1991). In other words, in order to gain compliance from higher status people, people who have lower status tend to use situationally proper or safe strategies to maintain a stable relationship (e.g., Tierney, 1989; Waldron, 1991), in this case a shortterm, task-oriented one.

The results of both the U.S. and the Japanese subjects showed that exchange of benefits and assertion compliancegaining strategies were used less frequently. Less frequent use of exchange of benefits and assertion might be explained by the fact that a lower status person may not be sure whether he or she could offer exchange or be assertive in a short-term relationship. An interesting culture-related difference was seen in exchange of benefits and assertion compliance-gaining strategies between the U.S. and the Japanese subjects. Although this study did not test the degree of selection of compliance-gaining strategies by different cultures, the descriptive statistics showed that the U.S. subjects replied that they would select exchange of benefits strategies more than assertion strategies while the Japanese subjects selected assertion strategies more than exchange of benefits. In other words, the results showed the U.S. subjects selected assertion strategy the least, while the Japanese subjects selected exchange of benefits the least.

Possible implications of these differences may lie in 
the cultural perception of what a risky strategy is. In order for U.S. lower status people to gain compliance, assertion strategies are relatively risky (Tierney, 1989), while exchange of benefits strategies are positively perceived (Neuliep \& Hazleton, 1985). For Japanese lower status people, offering an exchange as a way of narrowing psychological relationship distance (Howard, Blumstein, \& Schwartz, 1986) is risky because it might distort a vertical power hierarchy which Japanese culture values (Condon, $1984)$.

of the four compliance-gaining strategies, only assertion showed significant differences based on gender as well as cultural differences. Not surprisingly, male subjects scored higher on assertion than females. Although this study did not test a relationship between assertion strategies and females, the descriptive statistics showed an interesting result: Japanese females selected assertion more than U.S. males or females. The stereotyped image of Japanese females is that of passivity and obedience; yet, in response to a hypothetical situation, Japanese females reported they would select assertion compliance-gaining strategies more often than either U.S. males or females. This finding challenges generally accepted stereotypes for Japanese, especially for Japanese females.

A possible explanation for this finding is that Japanese females might have unconsciously registered their 
communication behavior as lower status through the use of politeness (Ide, Hori, Kawasaki, Ikuta, \& Haga, 1986). Japanese women who are raised to be feminine (Lebra, 1984) automatically use honorifics or politeness with any kind of compliance-gaining strategy. Therefore, it is assumed that Japanese females would use polite forms of expressions with assertion compliance-gaining strategies, as well as the other three strategies. Although Japanese females' selection of assertion strategies was an unexpected result, this may be related to a Japanese woman's ability to assert herself within a framework of polite language. The use of politeness with assertion strategies deserves further study.

\section{Rationalization}

In a relatively shallow relationship such as a shortterm, task-oriented relationship, people may try to make others quickly understand what they want. Brown and Levinson (1987) stated for rationalization: "Giving reason is a way of implying ...'you can help me,' and, assuming cooperation, a way of showing what help is needed" (p. 128). In this way, rationalization can convey the idea that help is needed at once. To present one's own request rationally helps the other person not only to understand the request better but also gives him or her the power to decide whether the request should be accepted or not (Kipnis \& Schmidt, 1984). In a relationship which consists of a leader who 
possesses power and regular group members who lack power, it is crucial for regular members to demonstrate to the leader that they recognize the leader's power, and yet still try to gain compliance. The results of this study confirmed that lower status people would select rationalization compliancegaining strategies. Both U.S. and Japanese subjects scored highest on the question items for rationalization.

Comparing U.S. and Japanese subjects, the results showed that the U.S. subjects used rationalization more than the Japanese subjects did. The result did not support hypothesis one: "Japanese lower status people who are in short-term, task-oriented relationships will use more rationalization compliance-gaining strategies than U.S. lower status people who are in short-term, task-oriented relationships." There are four possible reasons that may explain why the U.S. subjects selected rationalization compliance-gaining strategy more often than the Japanese subjects did: (1) The question items for rationalization compliance-gaining strategies may have been more favorable for the U.S. subjects; (2) the question items for rationalization compliance-gaining strategies may have been interpreted differently by the Japanese subjects; (3) the degree to which subjects have been involved in group projects may have reflected a greater or lesser ability to present a request rationally; and (4) the closeness of age between the U.S. subjects and the leader may have influenced 
the U.S. subjects selecting rationalization compliancegaining strategies.

The question items might be responsible for the U.S. people selecting more rationalization compliance-gaining strategies than the Japanese subjects did. The question items for rationalization compliance-gaining strategies were all associated with verbal skills such as explaining, logical reasoning, writing down justifications, and presenting information. Because U.S people who are relatively independent and individualistic are relatively used to presenting their thoughts verbally (Barnlund \& Araki, 1985; Hall, 1976; Nomura \& Barnlund, 1983) in order to gain agreement from a higher status person, a lower status person would present a request verbally. Thus, the fact that question items focused heavily on verbal communication for rationalization may be the reason why the U.S. subjects selected more rationalization strategies than did the Japanese subjects. Furthermore, while some question items, such as Q4, Q5, Q14, and Q15, included further definitions of the statement, the question items for rationalization compliance-gaining strategies did not have additional clarifications. Because Japanese people may rationalize their requests with deferring manners or roundabout expressions and because the statements had no additional clarifications, the Japanese subjects may have responded with a lower frequency of selection of 
rationalization compliance-gaining strategies.

Although the Japanese's general psychological concept of "amae" or dependency (Doi, 1962) might allow Japanese lower status people to say what they want to gain compliance from higher status people by presenting rationalization, the question items might have been interpreted differently by young Japanese subjects. Compared with the other three compliance-gaining strategies--ingratiation, exchange of benefits, and assertion--which all indicate relatively clear meanings shared by both cultures, rationalization may lend itself to different interpretation by the young Japanese subjects. In fact, the score of the reliability coefficient for rationalization was lower than the other three which implies that there might be a more ambiguous interpretation of rationalization by the U.S. and the Japanese subjects. It is assumed that experience can increase a person's skills in the use of compliance-gaining strategies (Applegate, 1982). Having been involved in group projects might be a factor for a gap between U.S. and Japanese subjects' selection of rationalization compliance-gaining strategies. The results showed that more U.S. subjects $(84.1 \%)$ replied they had been involved in group projects than Japanese subjects $(55.0 \%)$. It seemed that experience with group projects might increase awareness for the need to conform to group pressure. Although Japanese subjects also have experience conforming to group pressures, this 
experience was not reflected in the short-term, taskoriented relationship referred to in the survey questionnaire. In group projects, which generally have a leader and regular group members, the U.S. subjects may be more accustomed to communicating with a leader than the Japanese subjects. U.S. subjects may maintain a good relationship with a leader by presenting explanations or justifications in order to gain compliance from a higher status person. The Japanese subjects who have less experience with group projects might not have confidence in their relationship with their leader. However, a $t$-test for the Japanese subjects revealed there were no significant differences in selection of rationalization compliancegaining strategies whether they had experience with group projects or not. Therefore, experience with group projects can be eliminated.

The leader's age in the hypothetical scenario was 30. The average age for the U.S. subjects was 27 , while for the Japanese subjects, it was 20 . Older subjects, some of whom were older than the leader, may have interpreted rationalization compliance-gaining strategies differently than younger subjects. However, correlation coefficients for age and rationalization revealed no significant relationship. Therefore, the difference in average age between U.S. and Japanese subjects can be eliminated as an explanation for these results. 
Although it seems reasonable that the Japanese subjects having less experience in group projects and the small age differences between the U.S. subjects and the leader could explain the results contrary to hypothesis one, the additional statistical analyses did not support either explanation. Eliminating the two possible alternative explanations suggests that the Japanese may not act as theoretically presumed. The widely accepted cultural stereotypes about Japanese reliance on group conformity, in terms using rationalization compliance-gaining strategies, needs further investigation.

\section{Exchange of Benefits}

Exchange of benefits as a compliance gaining strategy as categorized by Kipnis, Schmidt, and Wilkinson (1980) includes offering help, personal-sacrifice, personal-favor, exchange, and reminding of past favors that the lower status person did for the leader. Exchange of benefits strategies imply a clear idea of what a person wants to get in the exchange. However, in spite of the fact that the exchange of benefits is clear, the total average scores of both U.S. and Japanese subjects showed that the exchange of benefits strategies were used least. Examining how the U.S. and the Japanese subjects replied to exchange of benefits compliance-gaining strategies, the results showed that the U.S. subjects selected exchange of benefits more than the 
Japanese subjects. Thus, hypothesis two: "U.S. lower status people who are in short-term, task-oriented relationships will use more exchange of benefits compliancegaining strategies than Japanese lower status people who are in short-term, task-oriented relationships" was satisfied. Major reasons for more U.S. subjects selecting exchange of benefits than the Japanese subjects may relate to the cultural values of egalitarianism and individualism. Whether individualism and egalitarianism are valued or not, power relationships exist in any situation, and a relatively egalitarian and individualistic culture might allow lower status people more opportunities for expressing their thoughts (e.g., Hofstede, 1984; stewart, 1971). This allowance can be seen in the U.S., in the hierarchical relationships within the classroom. The relative freedom that U.S. students, who are lower status, have in expressing their opinions to their teachers, who are higher status, can be considered a reflection of these egalitarian values (Ulrich, 1986).

Accordingly, in a relatively individualistic and egalitarian culture like that of the U.S., the ability of individuals to take responsibility for themselves is highly valued, as is taking positive action to accomplish personal goals (e.g., Hofstede, 1984; Stewart, 1971). Gaining compliance by offering personal sacrifice requires taking responsibility for one's own actions. Thus, a lower status 
person who is in an individualistic and egalitarian culture may well be more inclined to negotiate "give and take" conditions with a higher status person. Although an actual power hierarchy exists in short-term, task-oriented relationships, in the U.S. a lower status person actively narrows the power gap psychologically. Howard, Blumstein, and Schwartz (1986) stated that the psychological power gap is filled by exchange of benefit or bargaining. Exchange as a means of "give and take" raises a lower status person's psychological power while a higher status person still possesses actual power.

In contrast to people in the U.S., people in Japanese culture accept a vertical hierarchical relationship (Condon, 1984; Nakane, 1970). Japanese lower status people accept and behave based on a given position in the hierarchy. Thus, they would rather keep their relationship distance than narrow it. A lower status person offering exchange as a "give and take" condition to a higher status person might even be interpreted as intruding on the hierarchical structure, because a lower status person offering exchange implies he or she has an advantage over the higher status person (Befu, 1986). A Japanese person will choose not to offer an exchange in order to maintain a good relationship within a given hierarchical relationship. 


\section{Ingratiation}

In addition to the rationalization strategy, another effective compliance-gaining strategy indicated by both the U.S. and the Japanese was ingratiation. Ingratiation is an indirect compliance-gaining strategy that includes such elements as being humble and giving compliments, which are important components for lower status people trying to gain compliance from higher status people. In this study, the ingratiation strategies included sympathy, humbleness, admiration, a friendly manner, flattery, and waiting for receptive timing.

Studies by Brown and Levinson (1987) showed that making a request can be a threatening act. Because of this, lower status people might try to reduce this perception by using ingratiation as a compliance-gaining strategy with higher status people. Although a relationship lasts for a short period of time, lower status people try to maintain a good relationship with higher status people (Tierney, 1989, Waldron, 1991). In fact, as Johnson (1976) stated, indirect strategies can be effective and appropriate when they are used over the short-term.

Unlike previous research, which showed that females used indirect strategies such as ingratiation more than males (DuBrin, 1991), the results did not show differences based on gender. Males who have lower status selected ingratiation strategies equally often. A possible 
explanation for males' selection of ingratiation strategies is that males can use either direct or indirect strategies depending on the situation (Johnson, 1976). Because, by using ingratiation strategies, a lower status person can maintain a relationship with a higher status person as well as to gain compliance (Jones, 1964), ingratiation strategies are actively used by males and females.

Looking at females in the U.S. and Japan, the results showed that U.S. females selected ingratiation strategies more often than Japanese females. The results supported hypothesis three: "U.S. lower status females who are in short-term, task-oriented relationships will use more ingratiation compliance-gaining strategies than Japanese lower status females who are in short-term, task-oriented relationships."

It was assumed that within a framework of ingratiation strategies, humbleness would be used equally by U.S. and Japanese female subjects while the use of compliments would be significantly different between them. Being humble is one ingratiation strategy which emphasizes hierarchical relationships because it maintains distance by establishing a lower status person's recognition of a higher status person's power. For the U.S. female subjects who have been brought up being individualistic since childhood (Stewart, 1971), being humble is an active action, one deliberately chosen to gain compliance from a higher status person. For 
the Japanese female subjects, who have been brought up being feminine (Lebra, 1984), being humble is simply meeting a cultural expectation. Accordingly, Japanese females behave relatively humble manner without making a conscious effort. Whether being humble is consciously chosen or whether it is simply meeting a culturally based expectation, ingratiation as a humbleness strategy is used for keeping a certain hierarchical relationship.

Using compliments as an ingratiation strategy also emphasizes the existing hierarchical structure in a given situation (Jones, 1964). Like humbleness, cultural differences have a strong impact on the use of compliments. The U.S. subjects acknowledged power distances by giving compliments directly to a higher status person; yet, while doing so, they purposely minimized psychological power distances (Jones, 1964). In an egalitarian culture such as the U.S., women who make an effort to achieve personal goals are highly valued (Suzuki, 1991); therefore, the use of compliments is widely accepted and frequently used (Barnlund \& Araki, 1985).

The Japanese subjects indicated they would not use ingratiation strategies as much as the U.S. subjects would. The results imply that the Japanese subjects would rather keep a hierarchical distance between a lower status person and a higher status person, because upward compliments violate the hierarchical structure (Jones, 1964). Downward 
compliments (from a higher status person to a lower status person) are more often used than upward compliments (from a lower status person to a higher status person). For this reason, a lower status Japanese female's use of compliments might even have the undesired effect of causing suspicion on the part of the higher status person (e.g., Wortman \& Linsenmeier, 1977). In addition, a direct compliment may imply that a person is presumptuous (Jones, 1964) and does not respect the hierarchical relationship. Directly addressed ingratiation may imply that a lower status person has the capacity to evaluate a higher status person, that the lower status person knows what and how the higher status person should behave (Jones, 1964; Wortman \& Linsenmeier, 1977). Thus, Japanese people who are in a short-term, taskoriented relationship would use compliments by way of the third party rather than giving them directly to a higher status person (Barnlund \& Araki, 1985), for in this way a higher status person would not suspect that the lower status person's purpose was to try to gain compliance (Wortman \& Linsenmeier, 1977).

It is important to know the different cultural values of ingratiation strategies which affect a person's perceptions of other cultures. Judging other's communication behavior by one's own cultural values may cause misunderstanding. U.S. people may appear to be overfriendly; Japanese people may appear to be reserved. 
Whether ingratiation strategies, especially the use of compliments, are used purposely by U.S. females or as a part of the expectation of modesty by Japanese females, their purpose is to maintain a good relationship with a higher status person while they try to gain compliance. Being aware of these cultural differences in the use of ingratiation strategies contributes to better communication and understanding between a higher status and a lower status person regardless of cultural background.

\section{Assertion}

Unlike the other three compliance-gaining strategies, rationality, exchange of benefits, or ingratiation, all of which imply thoughtfulness (e.g., Kipnis \& Schmidt, 1984; Schmidt \& Kipnis, 1987), assertion strategies imply control over another person. In this study, assertion includes being a nuisance, confronting, reminding repeatedly, setting time deadlines, expressing anger verbally, and pointing out rules.

Unlike ingratiation, rationalization, and exchange of benefits, the choice of assertion strategies was influenced by both culture and gender. Assertion, a compliance-gaining strategy often associated with a masculine stereotype, such as "willing to take risks [or be] forceful" (Gaa, Liberman, \& Edwards, 1979, p. 594), meets gender expectations. This indicates that there would be a greater use of it by males 
than females. Accordingly, the results showed a significant difference based on sex. Meeting gender expectations in gaining compliance from another is more effective than not meeting them (Burgoon, Dillard, \& Doran, 1983). Even when in a position of lower status, males still select masculine compliance-gaining strategies such as assertion. The results supported previous studies that males can use both direct and indirect strategies (Johnson, 1976; Kipnis, Schmidt, \& Wilkinson, 1980). However, females' using direct strategies is not within gender expectations. Gender-based stereotypes are still strong.

The results for the use of assertion strategy were examined for both the U.S. and the Japanese males within the context of cultural differences and gender expectations. They showed that the Japanese male subjects selected assertion more often than the U.S. male subjects. Thus, hypothesis four: "U.S. lower status males who are in shortterm, task-oriented relationships will use more assertion compliance-gaining strategies than Japanese lower status males who are in short-term, task-oriented relationships" was not supported.

This result has three possible considerations which may explain why the Japanese male subjects selected assertion strategies more often than the U.S. male subjects did: The U.S. male subjects may have chosen assertion to a lesser degree in response to perceived social desirability; (2) the 
Japanese national characteristic of "amae" or dependency might play a role; (3) U.S. males may perceive that using assertion strategies is not appropriate in a given hierarchical structure.

While it may be true that U.S. lower status males select assertion strategies (Kipnis, Schmidt, \& Wilkinson, 1980), the places chosen for the survey, in this case colleges, might have influenced U.S. subjects responses. The study done by Heilbrun and Bailely (1986) suggested that U.S. middle-class college students might be more influenced by socially valued behavior when responding to a questionnaire about masculine and feminine traits than the general population. Therefore, it is assumed that social desirability might be responsible for results showing less frequent use of assertion strategies. Thus, in the questionnaire, the U.S. subjects might have responded that they would use less of assertion compliance-gaining strategies than they do normally.

The Japanese use of assertion strategies might be explained as a culturally exercised "amae," or dependency. Mutual dependency is possible because Japanese hierarchical structures are broken down into small units. In other words, within the greater hierarchy, there are many different levels of smaller hierarchical units. Thus, while the hierarchical structure of a small unit is explicit, the relationship distance between the lower status person and 
the higher status person is relatively close. Nakane (1970) stated that a lower status person is responsible for being loyal to a higher status person. In turn, a higher status person has a responsibility to take care of a lower status person. Thus, within the concept of mutual understanding based on hierarchical structure, lower status people can be assertive to higher status people. This is based on the Japanese cultural attitude in which an immediate leader and group members are closely tied (Nakane, 1970). The Japanese subjects responding to assertion strategies more than the U.S. subjects can even be accounted for by the fact that frankness is accepted in mutually dependent relationships. Thus, Japanese people maintain hierarchical structure by taking advantage of higher status people's roles as patriarchs. In other words, Japanese lower status people expect higher status people to understand their assertive behavior.

In an egalitarian culture such as the U.S.A., people try to minimize the distance of psychological power, although power hierarchies do exist and influence lower status people's communication behavior. While a majority of the Japanese male subjects were enrolled in the private college and studying in the U.S.A., a majority of the U.S. male subjects were enrolled in the publicly administrated colleges. This difference makes it more likely that the U.S. subjects have had experience in work places with a 
"top-down" management style common in the U.S.A. than the Japanese subjects. Condon (1984) stated that "American management is generally characterized as 'top-down' management, with plans and procedures determined at the top and implemented down the line" (p. 21). In addition, Chikudate (1991) stated that there were more authoritarian relationships in organizations in U.S. culture than in Japanese culture. Chikudate (1991) referred to this difference when he noted that in authoritarian figure relationships in Japan, people socialize outside of the work place, while in the U.S., workers keep socializing with people of higher status after work hours to a minimum. In the U.S., higher status people are perceived as authority figures rather than friends with whom to socialize. Thus, it is assumed that U.S. males would be sensitive to maintaining a given power relationship and would be careful not to use assertion strategies. Even when a relationship lasts only a short period of time, an individual's effort to maintain a good relationship with a higher status person is highly valued. Thus, for U.S. lower status males, recognizing that assertion strategies are risky in a given hierarchy is very important. 
SUGGESTIONS FOR FUTURE STUDIES

This cross-cultural, comparative study of compliancegaining strategies used by lower status people in U.S. and Japan gives rise to several suggestions for future study. The first is greater attention paid to sample selection. For instance, Japanese students who study in the U.S.A. are likely to come from more affluent socioeconomic classes than their U.S. classmates; thus, these differences in social class might contribute to variance in some of the questionnaire responses. For future study, selecting a college in which students' social classes are similar would help to narrow the gap between cultures.

The second suggestion is related to the external validity of the research. The use of question items from Kipnis, Schmidt, and Wilkinson's (1980) study, which heavily focused on the business working environment, shows a need to test whether this study is valid when used on student subjects. Also, it is crucial to test whether the question items from Kipnis et al.'s (1980) study are appropriate for Japanese people. In order to test this, it would be necessary to use Japanese subjects who live and work in Japan.

This study was based on an assumption that people may use their culturally determined communication styles in a short-term relationship; thus the hypothetical scenario was 
composed for an interaction between a lower and higher status person in the same culture. The third, it is suggested that a future study use the statistical method of within-subject design to measure whether or not subjects change their compliance-gaining strategies according to the nationality of a leader.

Lastly, to be fair and to reflect a social trend in which the number of women leaders is increasing both in Japan and the U.S.A. (e.g., Harper \& Hirokawa, 1988; Solo, 1989), a future study should also consider composing a hypothetical scenario with a woman leader. 
CHAPTER VI

CONCLUSION

The last chapter concludes this study from the theoretical point view and discusses its methodological implications and practical contributions.

\section{THEORETICAL IMPLICATIONS}

This research attempted to ascertain the ways that lower status U.S. and Japanese people gain compliance from higher status people. The research question "How do Japanese people and U.S. people who are in short-term, taskoriented relationships compare in their use of various tactics of upward influence?" was proposed to investigate cultural differences within this context. Overall, a relatively greater use of exchange of benefits, ingratiation, and rationalization compliance-gaining strategies appear to be associated with U.S. culture, while greater use of assertion compliance-gaining strategies appear to be associated with Japanese culture.

Although this study only dealt with a narrow range of communication situations, compliance-gaining strategies used 
in a short-term, task-oriented relationship, the results of this study indicated that there were some cultural differences, at least in the selection of compliance-gaining strategies.

Although the result of this study for assertion compliance-gaining strategies contradicted the hypothesis that U.S. males will use more assertion strategies than Japanese males, the results related to assertion strategies showed significant cultural differences between the U.S. and Japan: Japanese males selected more assertion strategies than U.S. males. Moreover, although this study did not test assertion strategies in detail, the descriptive statistics indicated the unexpected result that Japanese females selected more assertion strategies than either U.S. males or females. This result suggested that Japanese people may not act in a way consistent with the generally held cultural stereotypes, such as the Japanese being less self-assertive or more indirect.

It is impossible to make broad generalizations about cultural differences in communication styles based on this study. Moreover, different cultures have different interpretations of communication styles, which may imply that the scale of measurement responded to by the U.S. and Japanese subjects might have different meanings.

Since this study is based on the literature available in the U.S., these findings may mean that the research and 
information about U.S. culture is relatively accurate, while the information about Japanese culture might still be inadequate and/or biased by stereotyping. These results indicate the need for researchers to review generally accepted cultural stereotypes and available information.

\section{METHODOLOGICAL IMPLICATIONS}

Three compliance-gaining strategies--ingratiation, exchange of benefits, and assertion--showed reasonably high reliability, while rationalization showed low reliability by both the U.S. and Japanese subjects. The low reliability for rationalization raises concerns about using the question items which were taken from Kipnis, Schmidt and wilkinson's (1980) study. The subjects for the present study might have interpreted rationalization differently than the subjects used by Kipnis et al. (1980) over a decade ago. In other words, its face validity may have changed since 1980 .

Problems of face validity are typical of the inductive research method used by Kipnis et al. (1980). Schriesheim \& Hinkin (1990) stated that "Content [face] validity, critical for all scales, is a particular difficulty for new concepts and measures developed through inductive research" (p. 256). For example, it is easy to imagine a situation in which Q3, "I would explain the reasons for my request," would seem very appropriate for a classroom project, but Q12, "I would 
write down a detailed plan that justified my ideas" would seem quite presumptuous. The way a person uses rationalization compliance-gaining strategies, as well as the other three compliance-gaining strategies, may differ from one situation to another.

\section{PRACTICAL CONTRIBUTIONS}

Most studies about compliance-gaining strategies focused on downward direction, leaders to subordinates, and the attempt to increase production (e.g., Harper \& Hirokawa, 1988; Hirokawa \& Miyahara, 1986; Sullivan, Albercht, \& Taylor, 1991). However, effectiveness of leadership should include understanding of the way subordinates try to gain compliance from their leaders as well. Yukl (1981) stated that "in order to understand the effectiveness of a leader, it is necessary to consider... upward power of subordinates over the leader..." (p. 15). This study contributes not only to narrowing the gap between the number of studies conducted on downward and upward direction compliancegaining strategies but also affirms the importance of the perspectives of lower status people.

Finally, this study sought to increase the amount of research in the specific field of cross-cultural comparison. Moreover, the results of this study will promote understanding which, it is hoped, will lead to fair 
treatment of lower status people who are from different cultures. It also will contribute to the ability of higher status people to understand lower status communication styles in different cultures. As the number of these intercultural relationships increases, such as with jointventure and cultural exchange programs, the need for this kind of understanding will become ever more important. The results of this study emphasize the need to recognize cultural differences in compliance-gaining strategies and underscore that this recognition is crucial for understanding intercultural communication in short-term, task-oriented relationships in intercultural settings. 


\section{REFERENCES}

Applegate, J. L. (1982). The impact of construct system development on communication and impression formation in persuasive contexts. Communication Monographs, 49, 277289.

Bain, W. (1991). Japanese foreign investment in oregon: A case study. Portland, OR: Portland state University, International Trade Institute.

Barnlund, D., \& Araki, S. (1985). Intercultural encounters: The management of compliments by Japanese and Americans. Journal of Cross-cultural Psychology, 16(1), 9-26.

Befu, H. (1986). Gift-giving in a modernizing Japan. In T. Lebra \& W. Lebra (Eds.), Japanese culture and behavior (pp. 158-170). Honolulu, HI: University of Hawaii Press.

Bennett, M. (1986). Towards ethnorelativism: A developmental model of intercultural sensitivity. In $M$. Paige (Ed.), cross cultural orientation (pp. 27-69). Boston, MD: University Press of America.

Bradley, P, H. (1978). Power, status, and upward communication in small decision-making groups. Communication Monographs, 45, 33-43.

Brannen, A. P., Ramsey. S. J., Olsen, B. J., \& Wilt, B. (1979). The red thread and the white kimono: Japanese women, omote and ura. International Journal of Intercultural Relations, $\underline{3}(4), 473-486$.

Broverman, I. K. , Vogel, S. R., Broverman, D. M., Clarkson, F. E., \& Rosenkrantz, P. S. (1972). Sex role stereotypes: A current appraisal. Journal of Social Issues, $\underline{28}(2), 59-78$.

Brown, P., \& Levinson, S. C. (1987). Politeness: Some universals in language usage. New York: Cambridge University Press.

Buck, E. B., Newton, B. J., \& Muramatsu, Y. (1984). Independence and obedience in the United States and Japan. International Journal of Intercultural Relations 8, 279-300. 
Burgoon, M., Dillard, J., \& Doran, N. (1983). Friendly or unfriendly persuasion: The effects of violations of expectations by males and females. Human Communication Research, 10(2), 283-294.

Burgoon, M., Dillard, J., Doran, N., \& Miller, M. (1982). Cultural and situational influences on the process of persuasive strategy selection. International Journal of Intercultural Relations, $\underline{6}$, 85-100.

Burgoon, M., \& Miller, M. (1990). Overcoming resistance to persuasion via contiguous reinforcement and repetition of message. Psychological Reports, 66, 1011-1022.

Cathcart, D., \& Cathcart, R. (1988). Japanese social experience \& concept of groups. In L. A. Samover \& R. E. Porter (Eds.), Intercultural communication: A reader (pp. 186-192). Belmont CA: Wordsworth.

Chikudate, N. (1991). Cross-cultural analysis of cognitive systems in organizations: A comparison between Japanese and American organizations. Management International Review, 31(3), 219-231.

Clark, R. A. (1979). The impact of self interest and desire for liking on the selection of communicative strategies. Communication Monographs, 46, 257-273.

Clark, R, A., \& Delia, J., G. (1979). Topoi and rhetorical competence. Quarterly Journal of Speech, 65, 187-206.

Cohen, A, R. (1958). Upward communication in experimentally created hierarchies. Human Relations, 11, 41-53.

Condon, J. C. (1984). With respect to the Japanese. Yarmouth, ME: Intercultural Press.

Delia, J. G., \& O'Keefe, B. J. (1979). Constructivism: The development of communication in children. In $\mathrm{E}$. Wartella (Ed.), Children communicating: Media and development of thought, speech, understanding (pp. 157185). Beverly Hills, CA: Sage.

DeMente, B. (1981). The Japanese way of doing business. Englewood Cliffs, NJ: Prentice-Hall.

Dienesch, R. M., \& Liden, R. C. (1986). Leader-member exchange model of leadership: A critique and further development. Academy of Management Review, 11, 618-634. 
Doi, T. (1962). Amae: A key concept for understanding Japanese personality structure. In $R$. Smith \& R. Beardsley (Eds.), Japanese culture: Its development and characteristics (pp.132-139). Chicago: Aldine.

Doi, T. (1973). The anatomy of dependence. Tokyo: Kodansha International.

DuBrin, A. J. (1991). Sex and gender differences in tactics of influence. Psychological Reports, 68, 635646 .

Falbo, T. (1977a). Multidimensional scaling of power strategies. Journal of Personality \& Social Psychology, $\underline{35}, 537-547$.

Falbo, T. (1977b). Relationships between sex, sex role, and social influence. Psychology of Women Quarterly, 2(1), 62-72.

Fox, W. (1977). Japanese management: Tradition under strain. Business Horizons, 20 (4), 76-85.

French, J., \& Raven, B. (1959). The bases of social power. In D. Catwright (Ed.), studies in social power (pp. 150-167). Ann Arbor, MI: University of Michigan, Institute for social research, Research center for group dynamics.

Gaa, J. P., Liberman, D., \& Edwards, T. A. (1979). A comparative factor analysis of the Bem sex role inventory and the personality attributes questionnaire. Journal of Clinical Psychology, 35, (3), 592-598.

Gudykunst, W., \& Nishida, T. (1986). Attributional confidence in low- and high-context cultures. Human Communication Research, 12(4), 525-549.

Hall, E. (1976). Beyond culture. NY: Anchor Books.

Harman, C., Klopf, D., \& Ishii, S. (1990). Verbal aggression among Japanese and American students. Perceptual and Motor Skills, 70, 1130.

Harper, N. \& Hirckawa, R. (1988). A comparison of persuasive strategies used by female and male managers I: An examination of downward influence. Communication Quarterly, 36(2), 157-168. 
Hattori, T. (1992). Intercultural confrontation styles of culturally homophilous and culturally heterophilous Japanese and U.S. college students. Unpublished master's thesis, Portland State University, Portland, OR.

Heilbrun, A. B., \& Bailey, B. A. (1986). Independence of masculine and Feminine traits: Empirical exploration of a prevailing assumption. Sex Roles, 14, 105-122.

Hirokawa, R., Mickey, J., \& Miura, S. (1991). Effects of request legitimacy on the compliance-gaining tactics of male and female managers. Communication Monographs, 58, 421-436.

Hirokawa, R. \& Miyahara, A. (1986). A comparison of influence strategies utilized by managers in American and Japanese organizations. Communication ouarterly, $\underline{34}(3), 250-265$.

Hofstede, G. (1984). Culture's consequences: International differences in work-related values. Beverly Hills, $\mathrm{CA}$ : Sage.

Holtgraves, T. \& Yang, J. N. (1992). Interpersonal underpinnings of request strategies: General principles and differences due to culture and gender. Journal of Personality and social Psychology, 62(2), 246-256.

Howard, J. A., Blumstein, P., \& Schwartz, P. (1986). Sex, power, and influence tactics in intimate relationships. Journal of Personality and Social Psychology, 51(1), 102-109.

Ide, S., Hori, M., Kawasaki, A., Ikuta. S., \& Haga., H. (1986). Sex difference and politeness in Japanese. International Journal of the Sociology of Language, 58, 25-36.

Johnson, P. (1976). Women and power: Toward a theory of effectiveness. Journal of Social Issues, $32(3), 99-$ 110 .

Jones, E. (1964). Ingratiation: A social psychological analysis. NY: Appleton-Century Crofts.

Jorden, E. H. (1987) . Japanese: The spoken language. New Haven, CT: Yale University Press.

Jorden E. H. (Ed.). (1991). Japanese language instruction in the United States: Resources, practice, and investment strategy. Washington D.C.: Johns Hopkins University, National Foreign Language Center. 
Kindaichi, H. (1975). Nipponjin no gengohyogen [Japanese verbal behavior]. Tokyo: Kodansha.

Kipnis, D., \& Schmidt, S. (speakers). (1984). Becoming more persuasive person (cassette Recording No. 2499). Psychology Today.

Kipnis, D., Schmidt, S., \& Wilkinson, I. (1980) Intraorganizational influence tactics: Explorations in getting one's way. Journal of Applied Psychology, 65(4), 440-452.

Lebra, T. (1976). Japanese patterns of behavior. Honolulu, HI: University of Hawaii Press.

Lebra, T. (1984). Japanese women: Constraint and fulfillment. Honolulu, HI: University of Hawaii Press.

Liden, R. C., \& Mitchell, T. R. (1988). Ingratiatory behaviors in organizational settings. Academy of Management Review, 13, 572-587.

Marwell, G., \& Schmitt, D. R. (1967). Dimensions of compliance-gaining behavior: An empirical analysis. sociometry, 30, 350-364.

Miller, G., \& Burgoon, M. (1978). Persuasion research: Review and commentary. In B. D., Ruben (Ed.), Communication yearbook: Vol. 2 (pp. 29-47). New Brunswick, NJ: Transaction Books.

Nadler, L. B., Keeshan Nadler, M., \& Broome, B. J. (1985). Culture and the management of conflict situations. In W. B. Gudykunst, L. Stewart, \& S. Ting-Toomey (Eds.), Communication, culture, and organizational processes. (pp. 87-111). Beverly Hills, CA: Sage.

Nakane, C. (1970). Japanese society. Berkeley, CA: University of California Press.

Nakane, C (1978). Tateshakai no rikigaku [Dynamics of vertical society]. Tokyo: Kodansha.

Neuliep, J., \& Hazleton, V. (1985). A cross-cultural comparison of Japanese and American persuasive strategy selection. International Journal of Intercultural Relations, 9, 389-404.

Nomura, N., \& Barnlund, D. (1983). Patterns of interpersonal criticism in Japan and United States. International Journal of Intercultural Relations, I, $1-18$. 
Okabe, R. (1983). Cultural assumptions of East and West: Japan and the United States. In W. Gudykunst (Ed.), Intercultural communication theory: Current perspectives (pp. 21-44). CA: Sage.

Ota, A. (1989, september 09). Ex-envoy dedicates university. The oregonian, p. C2.

Porter, L. W., Allen, R. W. \& Angle, H. L. (1981). The politics of upward influence in organizations. Research in Organizational Behavior, $3,109-149$.

Porter, R. E., \& Samover, I. A. (1988). Approaching intercultural communication. In L. A. samover, \& $R$. E., Porter (Eds.), Intercultural communication: A reader $(\mathrm{pp}, 15-30)$. CA: Wadsworth.

Portland State University. (1991). Portland State University Bulletin 1992-1993: General catalog issue. Portland, OR: Author.

Ramsey, S. (1985) . To hear one and understand ten: Nonverbal behavior in Japan. In $L$. A. Samovar \& R. E Porter (Ed.), Intercultural communication: A reader ( $P P$. 307-321). Belmont CA: Wadsworth.

Read, R. (1991, March 25). Prestigious Japanese university eyes Oregon branch: Waseda University, which grooms the nation's future elite, is likely to pick Portland for its first overseas campus. The oregonian, pp. B1, 4 .

Read, W, H. (1962). Upward communication in industrial hierarchies. Human Relations, 15, 3-15.

Schermerhorn, J., \& Bond, M. (1991). Upward and downward influence tactics in managerial networks: A comparative study of Hong Kong Chinese and Americans. Asia Pacific Journal of Management, 8 (2), 147-158.

Schilit, W, K. \& Locke, E, A. (1982). Study of upward Influence in organizations. Administrative Science Quarterly, 27, 304-316.

Schlueter, D. W., Barge, J. K., \& Blankenship, D. (1990). A comparative analysis on influence strategies used by upper and lower level male and female managers. Western Journal of Speech Communication, 54, 42-65.

Schmidt, S., \& Kipnis, D. (1987, November). The perils of persistence. Psychology Today, pp. 32-34. 
Schriesheim, C. A., \& Hinkin, T. R. (1990). Influence tactics used by subordinates: A theoretical and empirical analysis and refinement of the Kipnis, Schmidt, and Wilkinson subscales. Journal of Applied Psychology, 75(3), 246-257.

Shibamoto, J. S. (1985). Japanese women's Ianguage. orlando, FL: Academic Press.

Shimanoff, S. (1980). Communication Rules: Theory and research. CA: Sage.

Singh, C. (1988). Behavioral strategies for influencing immediate superiors. Psychologia, 31, 34-41.

Smith, J. (1992). Women in charge: Politeness and directives in the speech of Japanese women. Lanquage in society, 21, 59-82.

Solo, S. (1989, June). Japan discovers woman power. Fortune, pp. 153-157.

Soumucho Toukeikyoku. (Ed.). (1989). Nippon no toukei [Statistics Japan]. Tokyo: Okurasho Insatsukyoku.

Stewart, E. C. (1971). American cultural patterns: A cross-cultural perspective dimensions of international education, number three. Regional Council for International Education.

Sugita, H. (1992). The concept of self-disclosure in initial interaction between strangers in Japan. Unpublished masters thesis, Portland State University, Portland, OR.

Sullivan, J., Albrecht, T., \& Taylor, S. (1990). Process, organizational, relational, and personal determinants, of managerial compliance-gaining communication strategies. The Journal of Business communication, 27(4), 331-355.

Suzuki, A. (1991). Egalitarian sex role attitudes: Scale development and comparison of American and Japanese women. Sex Roles, 24, 245-259.

Suzuki, T. (1986). Language and behavior in Japan: The conceptualization of personal relations. In T. Lebra \& W. Lebra (Eds.), Japanese culture and behavior (PP. 142157). Honolulu, HI: University of Hawaii Press. 
Tierney, P. (1989). The relationship between LMX and influence strategy choice. Paper presented at Academy of Management, Midwest meeting, columbus, Ohio.

Thompson, C. A., Ishii, S., \& Klopf, D. (1990). Japanese and Americans compared on assertiveness/responsiveness. Psychological Reports, $\underline{66}, 829-830$.

Triandis, H. C., \& Albert, R. D. (1987). Cross-cultural perspectives. In F. M Jablin., L. L. Putnam., K. H. Roberts., \& L. W. Porter (Eds.), Handbook of organizational communication: An interdisciplinary perspective (pp. 264-295). Newbury Park, CA: Sage.

Ulrich, K. (1986). Normative teacher and student role behaviors in the U.S. With a contrast to Japan. Unpublished master's thesis, Portland State University, Portland, OR.

Waldron, V. R. (1991). Achieving communication goals in superior-subordinate relationships: The multifunctionality of upward maintenance tactics. Communication Monographs, 58, 289-306.

Watanabe, S. (1990). Framing in American and Japanese group discussions. Unpublished doctoral dissertation, Georgetown University, Washington, D.C.

Webster's third new international dictionary. (1986). Springfield, MA: Merriam-Webster.

Wheeless, L., Barraclough, R., \& Stewart, R. (1983). Compliance-gaining and power in persuasion. In $\mathrm{N}$. Bostrom (Ed.), Communication yearbook; Vol. 7 (pp. 105-145). Beverly Hills, CA: Sage.

Wortman, C. B., \& Linsenmeier, J. A. (1977). Interpersonal attraction and techniques of ingratiation in organizational settings. In B. Staw., \& G. Salancik (Eds.), New directions in organizational behavior ( $p p$. 133-178). Chicago, IL: st. Clair Press.

Yukl, G. A. (1981). Leadership in organizations. Englewood Cliffs, NJ: Prentice-Hall.

Zikopoulos, M., Sutton, E., \& Julian, A. (Eds.). (1992). open doors 1991/92: Report on international educational exchange. NY: Institute of International Education. 
APPENDIX A

INFORMED CONSENT 
I, subject in the research project about interpersonal communication style conducted by Miyoko Fuse under the supervision of Dr. David Ritchie.

I understand that the project involves answering demographic information questions, reading a hypothetical scenario, and answering questions regarding the scenario and others regarding a group project. I understand that there are no anticipated risks to me, that no identifying information will be associated with my responses, and that my responses will be entirely confidential.

It has been explained to me that the purpose of this study is to learn about interpersonal communication styles.

I may not receive any direct benefit from participation in this study, but my participation may help to increase knowledge which may benefit others in the future.

Miyoko Fuse offered to answer any questions I may have about the study. I have been assured that all information I give will be kept confidential and that the identity of all subjects will remain anonymous.

I understand that I am free to withdraw from participation in this study at any time without any penalty. I have read and understand the foregoing information and agree to participate in this study.

Date: Signature:

Note: If you have concerns or questions about this study, please contact Dr. David Ritchie (503)725-3550, or the Chair of the Human Subjects Research Review Committee, Office of Grants and Contracts, 105 Neuberger Hall, Portland State University, (503)725-3417. 
APPENDIX B

COVER LETTER FOR THE SUBJECTS 
Dear Respondent:

My name is Miyoko Fuse. I am a graduate student in the Department of Speech Communication at Portland state University, Portland, oregon. This questionnaire represents a portion of my thesis project under the supervision of Dr. D. Ritchie. The purpose of the questionnaire is to learn more about interpersonal communication styles.

This research packet consists of an informed consent sheet, a demographic information sheet, and a research questionnaire. Because of the concern of the Human subjects Research Review Committee for participants in research studies, I ask you to read the informed consent and sign your name before answering the questionnaire. There is no obligation for you to participate in this research and you may withdraw at any time. I assure you that if you participate, all information given in this questionnaire will remain anonymous and confidential.

Please read the informed consent carefully and sign your name if you are willing to participate in the research. After you sign your name, please answer the questionnaire. It will take about 10 minutes for you to complete this questionnaire. I would appreciate your participation.

Thank you very much.

Miyoko Fuse 
APPENDIX $C$

DEMOGRAPHIC INFORMATION SHEET

FOR THE U.S. SUBJECTS 


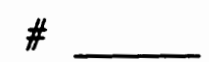

Please answer the following general questions.

1. sex: Male_. Female

2. age:

3. Nationality/Ethnicity:

4. Major:

5. Academic standing:

Freshman _. Sophomore - Junior

Senior Postbac Graduate

6. Have you lived in or visited Japan?

Yes No

7. If yes, how long?

8. Have you ever worked for or with a Japanese company? Yes No

9. If yes, how long?

10. How long have you studied Japanese?

11. If you are not originally from the U.S., how long have you lived in the U.S.A.?

Thank you very much. Please go on to the next page. 


\section{APPENDIX D}

\section{DEMOGRAPHIC INFORMATION SHEET}

FOR THE JAPANESE SUBJECTS 
$\#$

Please answer the following general questions.

1. sex: Male - Female

2. age:

3. Nationality/Ethnicity:

4. Major:

5. Academic standing at U.S. college:

Freshman - Sophomore - Junior

Senior - Postbac - Graduate ESL only

6. Are you an ESL student?

Yes No

7. If so, how long ?

8. How long have you lived in the U.S.A.?

9. Have you ever worked in the U.S.A. (on/off campus)? Yes No

10. If yes, how long?

Thank you very much. Please go on to the next page. 
APPENDIX E

SCENARIO FOR THE U.S. SUBJECTS 
This packet consists of a short scenario and questions. Please read the scenario first and then choose the most appropriate number from 1-almost never to 6-almost always for each question.

Scenario

Please imagine that you are involved in a group research project for a class. Because you are studying Japanese language and culture, and also because you can use the project as a future reference, you would like to get a high grade for the project.

So that each individual will do his or her job well, and all group members will cooperate during the project, the instructor will base half of the grade on each individual's performance and the other half on the group's performance as a whole. Each individual will be assigned a different task: Some tasks are interesting and others are boring.

The group was formed at the beginning of the term and will last the entire term. Getting the project accomplished will require outside meetings as well. The professor selected a U.S. male student, about 30 years old, as the group leader because of his expertise in the project topic. The group leader randomly assigned tasks to individuals during the first meeting, when all the group members were present. After this first group meeting, you looked over your task while having coffee at the cafeteria by yourself. You noticed that the task which you were assigned seemed boring to you, although it might not be boring to someone else. It also seemed like it may take too much of your time. Because the task was just assigned and because accomplishing the task will influence your grade, you would like the leader to change your task. 
APPENDIX F

SCENARIO FOR THE JAPANESE SUBJECTS 
This packet consists of a short scenario and questions. Please read the scenario first and then choose the most appropriate number from 1-almost never to 6-almost always for each question.

Scenario

Please imagine that you are involved in a group research project for a class. Because you are studying in the U.S.A., and also because you can use the project as a future reference, you would like to get a high grade for the project.

So that each individual will do his or her job well, and all group members will cooperate during the project, the instructor will base half of the grade on each individual's performance and the other half on the group's performance as a whole. Each individual will be assigned a different task: some tasks are interesting and others are boring.

The group was formed at the beginning of the term and will last the entire term. Getting the project accomplished will require outside meetings as well. The professor selected a Japanese male student, about 30 years old, as the group leader because of his expertise in the project topic. The group leader randomly assigned tasks to individuals during the first meeting, when all the group members were present. After this first group meeting, you looked over your task while having coffee at the cafeteria by yourself. You noticed that the task which you were assigned seemed boring to you, although it might not be boring to someone else. It also seemed like it may take too much of your time. Because the task was just assigned and because accomplishing the task will influence your grade, you would like the leader to change your task. 
APPENDIX G

QUESTIONS 
In this kind of situation, what would you do? Please rate the following strategies on how likely you would use them.

1

almost

never
3

4
5

6

almost

always

1. Before asking the leader to change my task I would make the leader feel good about me.

2. I would offer help to the leader if the leader would agree to change my task.

3. I would explain the reasons for my request.

4. I would become a nuisance (keep bugging the leader until he did what I wanted).

5. I would offer an exchange (e.g., if you change my task, I will do something for you).

6. Before asking about changing my task, I would act in a friendly manner to the leader.

7. I would point out that there are rules which require the leader to comply with my request.

8. I would use logical reasoning to convince the leader.

9. I would remind the leader of past favors that I have done for him.

10. I would wait until the leader appeared in a receptive mood before asking.

11. I would set a time deadline for the leader to do what I asked. 
$\begin{array}{llllll}1 & 2 & 3 & 4 & 5 & 6 \\ \text { almost } & & & & & \text { almost } \\ \text { never } & & & & & \text { always }\end{array}$

12. I would write down a detailed plan that justified my ideas.

13. I would express my anger verbally.

14. I would make the leader feel important by saying statements such as, "You are the only one with the ability to handle this group."

15. I would offer to make a personal sacrifice if the leader would do what I want (e.g., work late, work harder, do his share of the work, etc).

16. I would have a showdown in which I would confront the leader face-to-face.

17. I would present the leader with information in support of my point of view.

18. I would show my sympathy about the added problems that my request caused.

19. I would repeatedly remind the leader about my request.

20. I would do personal favors for the leader.

21. I would act very humbly to the leader while making my request.

Please go on the next page. 
Please indicate your answer from:

1-not at all (never) to 6-yes, very much.

1. How realistic do you think the scenario is?

2. Do you think the group leader's age would influence your communication style?

3. Do you think the group leader's gender would influence your communication style?

4. Have you had any group projects in any class before?

Yes

No

I would appreciate it if you would write any comments you have about the survey. If you need more space, please use the back of this page.

Thank you very much for your participation! 
APPENDIX H

COVER LETTER FOR JAPANESE LANGUAGE INSTRUCTORS 
Miyoko Fuse

1002 SE 26th

Portland OR 97214

(503) 236-3393

date

name

address

Dear Japanese Language Instructor

My name is Miyoko Fuse, a graduate student in Speech

Communication at Portland state University. I am writing a master's thesis regarding intercultural communication under the supervision of Dr. David Ritchie.

I wish to conduct my research with U.S. students who study Japanese language as well as Japanese students who are enrolled in U.S. colleges.

I would appreciate it if I could conduct a survey with your students. The survey will take approximately ten minutes. I would be grateful if you could arrange the day and time for my survey. I will call you to discuss the possibility of making these arrangements. Thank you very much for your time and consideration.

Sincerely,

Miyoko Fuse 
APPENDIX I

COVER LETTER FOR INSTRUCTORS OF JAPANESE STUDENTS 


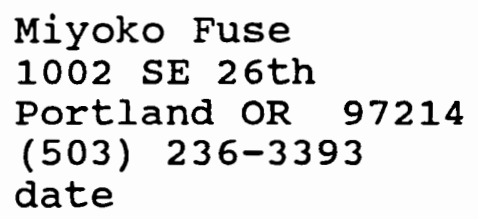

name

address

Dear English as a Second Language Instructor

My name is Miyoko Fuse, a graduate student in speech Communication at Portland State University. I am writing a master's thesis regarding intercultural communication under the supervision of Dr. David Ritchie.

I wish to conduct my research with the Japanese students who are enrolled in U.S. colleges, as well as the U.S. students who study Japanese language. I would appreciate it if I could conduct a survey with your Japanese students. The survey will take approximately ten minutes. I would be grateful if you could arrange the day and time for my survey. I will call you to discuss the possibility of making these arrangements. Thank you very much for your time and consideration.

Sincerely,

Miyoko Fuse 
APPENDIX J

JAPANESE TRANSLATIONS 


\section{司意書}

私、 は布施美代子か、、リッチー教投の指得下で行なっている リサーチプロジェクト「インターパーソナル コミュニケーション スタイル」の 被碀者になることに応します。

このリサー-チか、一般貫問に答えること、シナリオを読んで、それに成する買閣に 答えること、そして、クループブロジェクトに関する留問に答えること、を承知して います。

私の回答したことが、私に何の損失をももたらさないこと、名前、身分、を証さない こと、完全积密湖守であること、を理解します。

私は、このリサーチの目的が、インターパーソナル コミュニケーションのスタイル を知ること、にあることを裞明されました。

このリサーチに参加することが、遉接、私自身の利益にならないかも知れませんが、 将来、他の人建の知識を高めることに頁献することと、思います。

布施美代子から、このリサーチについての西䦓に答える、との申し出がありました。

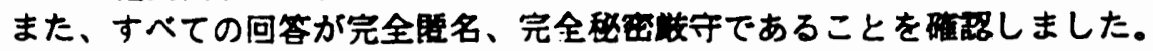

私は、このリサーチプロジェクトへの参加をいつでも故萧していいこと、それに 対するペナルティの無いこと、を理解しています。

私は上記を諳み、内容を理解し、そして、このアンケーートに参加することに同息 します。

年月日 署名

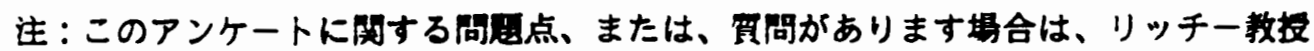

(503) 725-3550 あるいは Chair of Human Subjects Research Committee, Office of Grants and Contracts. 105 Neuberger Hall. Portland State University, (503) 725-3417 まで、こ連絡下さい。 
日本人学生の皆様へ

择辟

私は、ボートランド州立大学售士棵程スピーチコミュニケーション学部、に在籍 しております布施美代子と申します。このアンケートは、リッチー教率の指望下で 書いております答士詥女のリサーチの一部をなすものです。アンケートの目的は 「インターパーソナル コミュニケーション スタイル」を調㚗するものです。

このアンケート小冊子はは同意語、一般賈問、そして、アンケート用紙が入って います。まことに恐れ入りますが、アメリカの教育栦闻の規䄪により、アンケートに

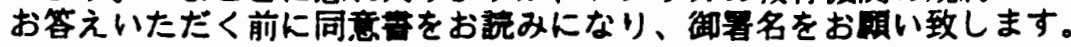

このアンケートは任意夸加ですので、アンケートにお答えにならなくても途中で

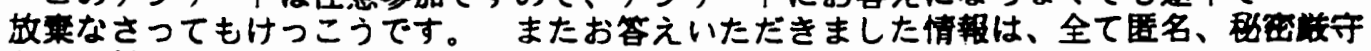
として报われます。

それでは、同意書をよくお讜みになった上で、アンケートにお答えいただける方は 御兴名をお賏い致します。全部お答えいただくのに約10分程かかります。

どうもありがとうこざいます。

敬具

布施美代子 
恐れ入りますか、下記の筫問にお答えください。

1) 性别： 男 女

2)年令:

3）国籍 :

4）専攻：

う）アメリカの大学では何年生ですか。

1 年生 - 2 年生 . 3 年生

4 年生 ・ ポストパック - 大学院生

ES L only

6) E S Lに所属しいていますか。 はい いいえ

7）（6）にはいと お答えの方、期間はどれ位ですか。

8) アメリカには何年住んでいますか。 年 月

9）アメリカで詣いたことはありますか。（校内、校外とも） はい - いいえ

l0)（9）にはいと お答えの方、どれ位の期间湖きましたか。

どうも有期うこさいました。どうぞ、次にお進み下さい。 
この項は、仮に設定された状況のシナリオと筫問から成り立っています。シナリオを お読みになってから、各質問ことに適当と思かれる数字（1ーめったにとらない から бーたいていいつもとる) をお答え下さい。

状況のシナリオ

あなたがクラスのクループプロジェクトに、かかわっているとします。 せっかく、 アメリカの大学で勉強していることだし、このプロジェクトの経験が、捋来の役に立つ だろうということで、あなたはこのプロジェクトで良い成樌をとりたい、と謴っていると します。

教投は、個人個人が良い仕事をするように、そしてまた、クルーブ全体が協力しあうよ うに、成謮の半分は㧽人個人の仕事で採点をし、後の半分はグループ全体を採点します。 各生徒は、それぞれに違う出事を受け持ちます。 仕事は面白いものからつまらないもの まであります。

クルーブは学期の始めに組まれ、学期中ずっと䋛䌇します。グループミーティングは クラス外でも行なわれます。数投が、メンバーの中から、30才位の日本人の男性を、

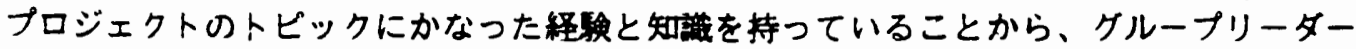
に選びました。クループリーダーは、メンバーが全員集まった第一回目のミーティング で、ランタムに（通当に）、各自に仕事を割り当てました、そのミーティンケの後で、 あなたは、一へで、カフェテリアでコーヒーを約みながら、与えられた仕事を見直しまし た。そこであなたは、その仕事が、他の人にとっては面白いかもしれないけれども、 あなたにとっては、つまらなそうな事に気付きました。時间的にも少し荷が重い気が しました。出事は、たつた今、与えられたばかりですし、又、仕事の出来が、あなたの 成䋖に影害することもあり、あなたはリーダーに代事をかえて欲しいと思います。 
さて、あなたならこの䓪合どうしますか。あなたか，かったにとらないだろう、と思われ る態度に1、たいていいつもとるだろう、と思むれる態度に 6 、を基準として下記の質問 にお答え下さい。
1
2
3
4
5
6

めつたに

とらない態度

1）仕事を变えて欲しい、と要求する前に、リーダーが自分に良い感情を 持つようにする。

2）もし仕事を変えてくれるならは、リーターの為に何かをすると言う。

3）仕事を変えて欲しい理由を説明する。

4) リーターに縝がらせをし始める。（例えは、私の要求を閒き入れて くれるまで、しつこく迫る。）

5）例えば、もし仕事を変えてくれれは、奴さんのために何かをすると 交换条件をだす。

6 ）仕事を変えて欲しい、と要求する前に、愛想を良くする。

7）リーダーはメンバーの要求には応じる、というルールがあると言う事を 指摘する。

8）筋道の通つた理由でリーダーを説得する。

ヨ）私が前にリーダーに頼まれ事をしてあげた事を思い出させる。

１0）リーダーが話を開いてくれそうなふん用気になるまで待つ。

1 1 ）リーターに、出事を変えてく九る期日を、設定する。 
1

2

3

4

5

6

めつたに

とらない䫺度

12）私の要求を正当化する詳絴な計画を書く。

13）口頭で自分の立胉を表現する。

14）例えは「奴さんだけがグルーブを梳率する力がある」等と言って リーダーが重要であるように照じさせる。

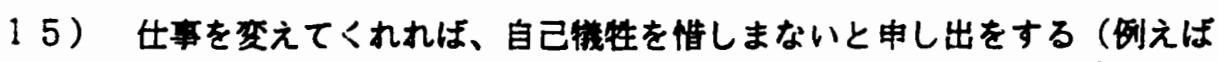

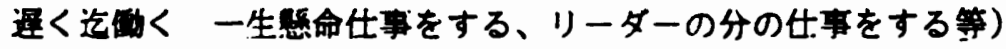

16)リーダーと、直接一対一で微底的に話し合いをする。

17）私の要求を支持する资料を提出する。

18）リーターに、余計な閭题を持ち込んで申し分けない、といろ 表現をする。

$19)$ リーダーに何回も私の要求について高う。

20）リーダーの個人的な体頼严を引き受ける。

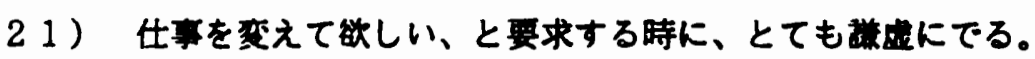

次のページにお進みください。 
下記の質問に1一全然思わない から 6一全くそう思う、を基㴖にお答えください。

1）このシナリオは現実的だと思いますか。

2）クループリーターーの年令が、あなたのコミニニケ-ションスタイルに 影辢すると思いますか。

3）グループリーダーの性別が、あなたのコミュニケーションスタイルに 影震すると思いますか。

4） 今までに、クラスのクループプロジェクト（どんなクラスでも）を 経験したことはありますか。 はい Wい

このアンケートでお気付きになったこと、こ意見、こ䋆想など、お聞かせください。 紙面が足りない場合は重をお使いください。 